\title{
Biostratigraphy of the Hareelv Formation (Upper Jurassic) in the Blokelv-1 core, Jameson Land, central East Greenland
}

\author{
Peter Alsen and Stefan Piasecki
}

\begin{abstract}
The Hareelv Formation in the Blokelv- 1 core is biostratigraphically subdivided by means of ammonite and dinoflagellate cyst stratigraphy. The succession ranges from the Oxfordian $C$. densiplicatum Chronozone to the Volgian P. elegans Chronozone. The mudstones of the Blokelv-1 core are characterised by large amounts of amorphous organic matter. This hampers the preparation and identification of dinoflagellate cysts, which are also commonly degraded and corroded. Ammonites, on the other hand, are common and well-preserved in the core, contrasting with that observed in the equivalent facies and stratigraphic interval at outcrop. Integration of the ammonite and dinoflagellate cyst biostratigraphical data yields a robust chronostratigraphic subdivision of the middle Oxfordian - lowermost Volgian cored section.
\end{abstract}

Keywords: Jameson Land Basin, East Greenland, ammonites, dinoflagellate cysts, biostratigraphy, chronostratigraphy, Oxfordian, Kimmeridgian, Volgian

\author{
P.A. \& S.P., Geological Survey of Denmark and Greenland, Øster Voldgade 10, DK-1350 Copenhagen K, Denmark. \\ E-mail:pal@geus.dk \\ S.P., also Geological Museum, Natural History Museum of Denmark, University of Copenhagen, Øster Voldgade 5-7, DK-1350 \\ Copenhagen K, Denmark. E-mail: stefan.piasecki@snm.ku.dk
}

Ammonites and dinoflagellate cysts have been applied as the principal means of biostratigraphic dating of the fully cored Blokelv-1 borehole (GEUS 511101), which drilled through $234.80 \mathrm{~m}$ of the Upper Jurassic in southern Jameson Land (Figs 1-3). It was the first of three core wells drilled by GEUS in 2008-2010 as part of a campaign that aimed to document the petroleum potential of the Upper Jurassic mudstone successions in central East Greenland and North-East Greenland (Bojesen-Koefoed et al. 2009, 2014). Based on outcrop data, these sediments have previously only shown limited source-rock potential (see Bojesen-Koefoed et al. 2018, this volume), yet they are time-equivalent with the prolific source rocks of the UK and Netherlands North Sea (Kimmeridge Clay Formation), the Norwegian North Sea (Draupne Formation) and the Norwegian Sea (Spekk Formation; Brekke et al. 1999, 2001; references in Bojesen-Koefoed et al. 2018, this volume).

The present study of this potential source-rock succession in East Greenland has its background in the growing industry interest in areas of offshore NorthEast Greenland. The United States Geological Survey (USGS) assessment of undiscovered oil and gas resources in the Arctic promoted the basins of offshore North-East Greenland as being amongst the most important frontier areas for petroleum exploration (Gautier 2007; Gautier et al. 2011). The Danmarkshavn and Thetis Basins are interpreted to include several kilometre-thick Mesozoic successions and have been the subject of particular interest (Hamann et al. 2005), yet the validity of the source rock represents a key risk factor in these basins. The purpose of the drilling campaign onshore eastern Greenland 


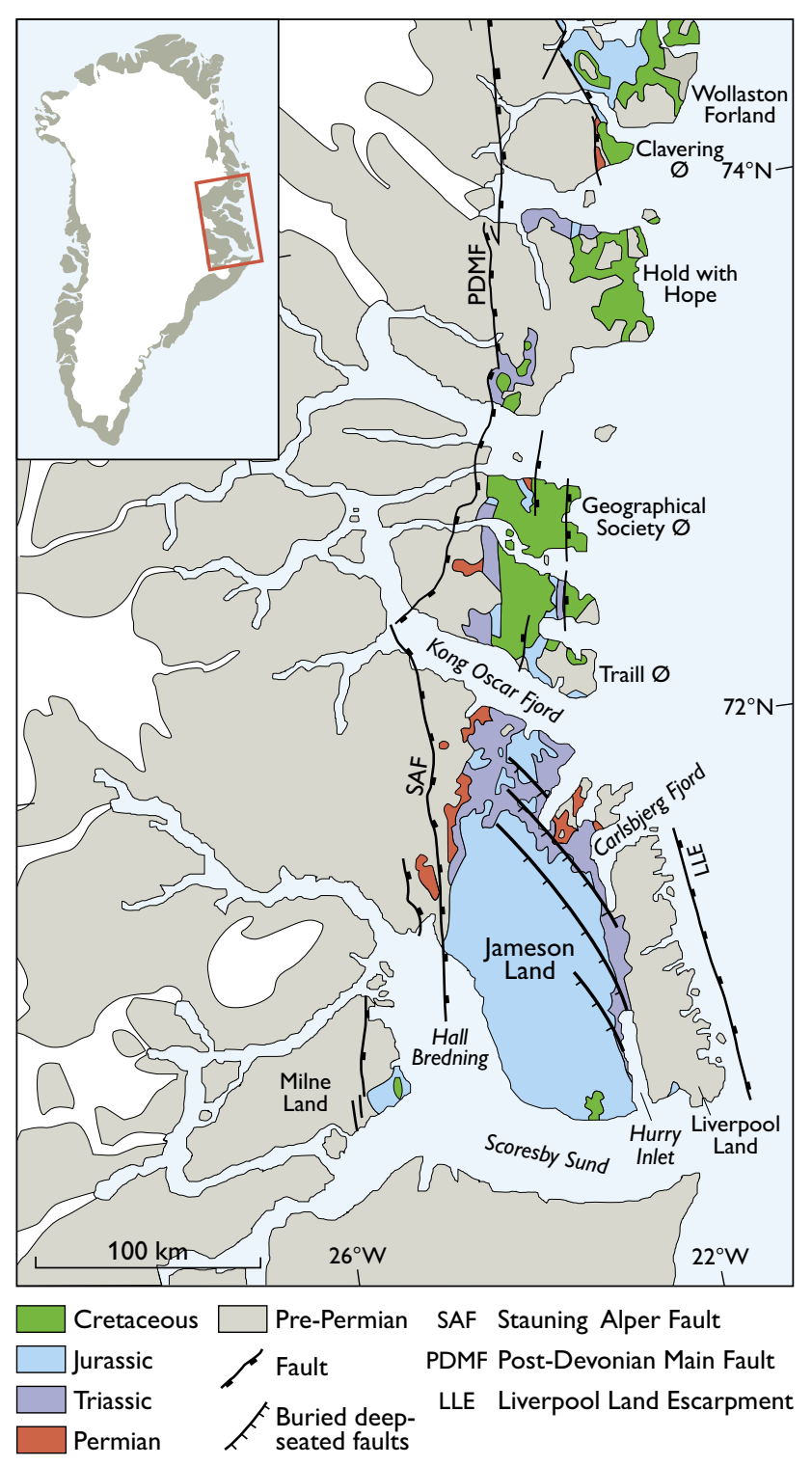

Fig. 1. Simplified geological map of eastern Greenland showing the distribution of Mesozoic rocks and major structures.

therefore was to investigate fully the source-rock potential of the Upper Jurassic succession.

A suite of analyses was undertaken in the Blokelv-1 borehole study, as presented in this bulletin, in order to characterise this important Upper Jurassic reference section for the northern North Atlantic region; an integrated study of the palyno- and ammonite biostratigraphy was a central element in this study and forms the subject of this paper. Complementary core analysis programmes were subsequently undertaken by GEUS in fully cored boreholes drilled in the Bernbjerg Formation in the Wollaston Forland Basin of North-East Greenland to extend knowledge of the Jurassic - Lower Cretaceous petroleum potential both stratigraphically and geographically, and in different basin settings (Fig. 1). The results of these subsequent investigations will be presented elsewhere.

\section{Previous biostratigraphic studies of the Upper Jurassic in the Jameson Land Basin}

A very well-preserved Upper Jurassic ammonite succession has been known from Milne Land at the western margin of the Jameson Land Basin since the work of Spath $(1935,1936)$. The collections on which this work was based were made by A. Rosenkrantz in the Scoresby Sund area during Lauge Koch's 1926-1927 mapping expedition in eastern Greenland (Rosenkrantz 1929). Spath's two monographs describe the ammonites from the Oxfordian - Lower Kimmeridgian and the Upper Kimmeridgian - Volgian. Subsequently, Sykes \& Surlyk (1976) and Sykes \& Callomon (1979) revised the boreal Oxfordian ammonite zonation and applied it to the successions in East and North-East Greenland. Callomon \& Birkelund (1982) and Birkelund \& Callomon (1985) refined Spath's ammonite stratigraphy in Milne Land, after revisiting and undertaking bed-by-bed collection in the key sections on the eastern flank of Hartz Fjeld, and adding material from the Visdal, Bay Fjelde and Aldinger Elv areas (Fig. 2). The resulting stratigraphic scheme remains very robust with an established ammonite faunal succession of 11 Oxfordian faunal horizons (Faunas 3-13 in Callomon \& Birkelund 1980), 10 Kimmeridgian faunal horizons (faunas 14-23 in Callomon \& Birkelund 1980; Birkelund et al. 1984; Birkelund \& Callomon 1985) and 24 lower and middle Volgian faunal horizons (faunas 24-47 in Callomon \& Birkelund 1982). Including two Middle Jurassic faunas, the succession totals 47 Jurassic faunal horizons in Milne Land. The prefix M is used here to denote the Bathonian-Volgian Milne Land faunal horizons (i.e. M-1 to M-47) to clearly differentiate them from the stratigraphically slightly overlapping BajocianOxfordian J-prefixed ammonite faunal horizons ( J-1 to $\mathrm{J}-41$ ), described from nearby Jameson Land (Callomon 1993, 2003). This usage follows Larsen et al. (2003) and Callomon et al. (2015). The Upper Jurassic ammonite zonation established in Milne Land offers a robust stratigraphic reference/framework to which studies carried out on the Upper Jurassic elsewhere in East and NorthEast Greenland can be referred. The Late Jurassic ammonite fauna in Jameson Land, where Blokelv-1 was drilled, 


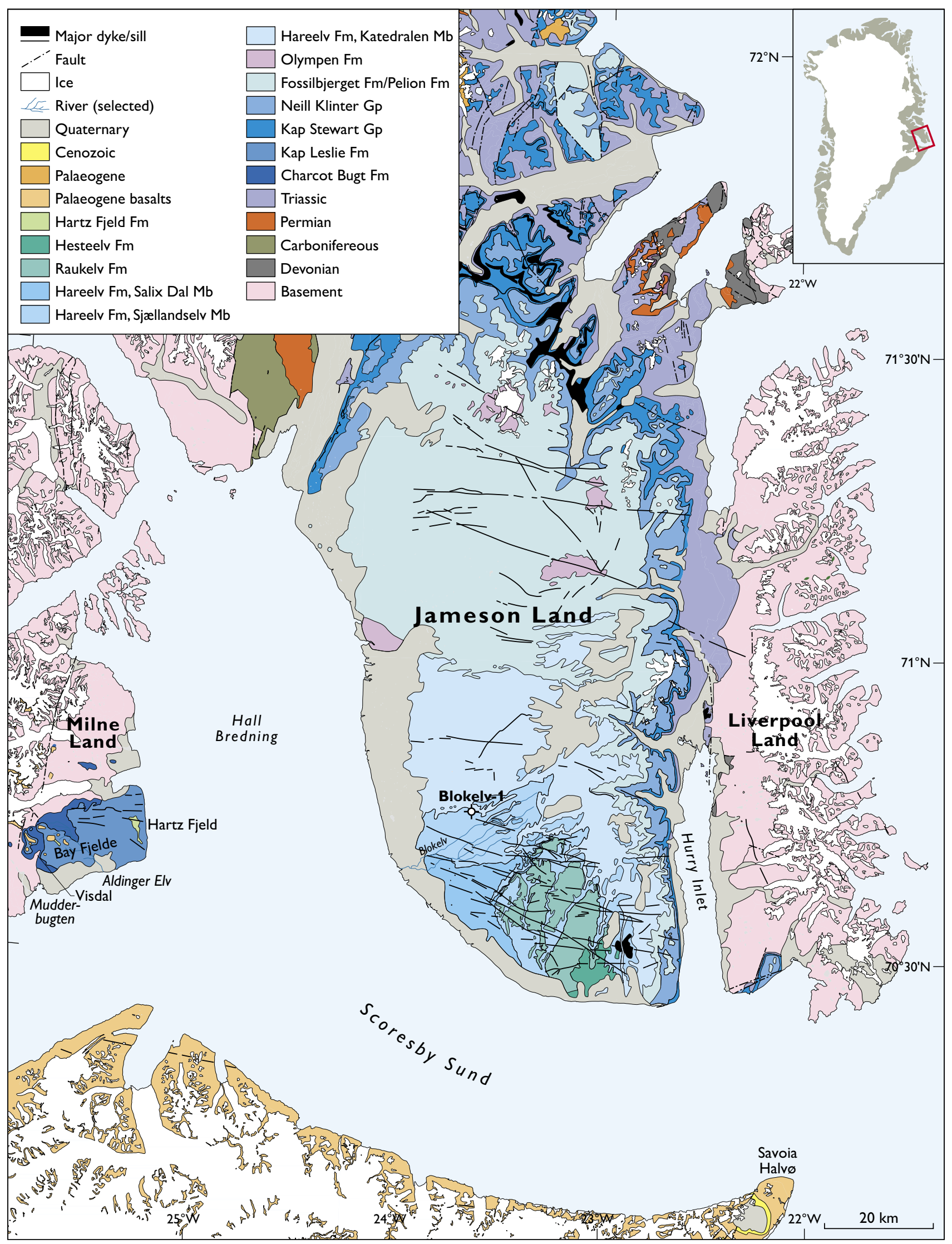

Fig. 2. Geological map of Jameson Land showing the location of the Blokelv-1 drill site. Only selected (named) rivers are indicated. 


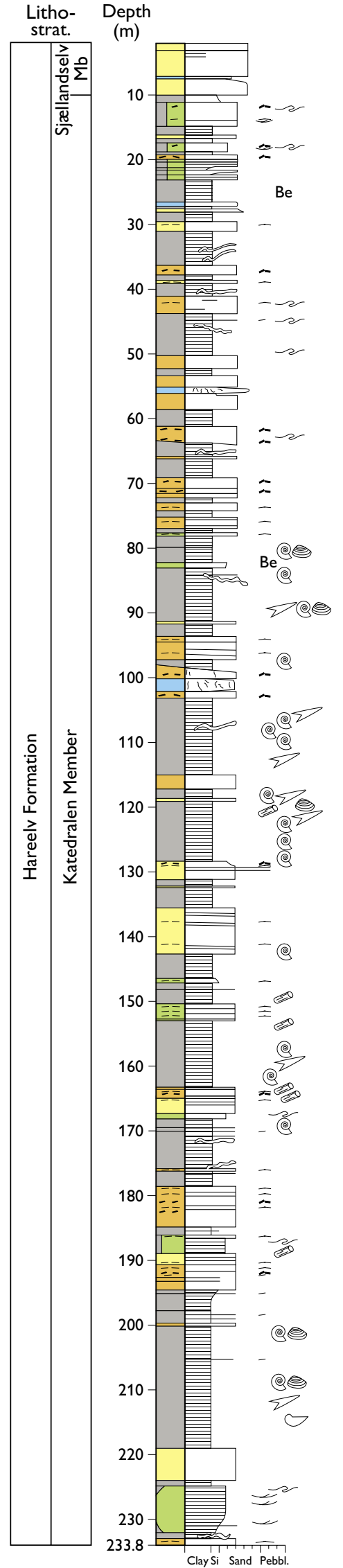

Fig. 3. Lithological log of the Hareelv Formation in the Blokelv-1 core; the succession is dominated by the Katedralen Member, capped by a thin interval of the Sjællandselv Member.

\section{Lithology}

\section{Mudstone}

Heterolith

(mudstone/sandstone)

Sandstone

Sandstone,

remobilised (intruded)

Igneous intrusion

Structures, biota

Parallel lamination/ bedding

- Diffuse stratification

- Ripple cross-lamination

Wavy bedding

slump

$\approx$ Sandstone intrusion

-- Small mudstone intraclasts

- Large mudstone clast

Be Bentonite

- Coalified wood

$\checkmark$ Belemnite

(a) Ammonite

C) Bivalve

$\circlearrowleft$ Brachiopod is commonly represented by crushed, incomplete and poorly preserved specimens in contrast to the common 3D-preserved mould and steinkern-preservation of the Milne Land material.

Subsequent to the establishment of the ammonite succession and stratigraphy in Milne Land and Jameson Land, dinoflagellate stratigraphy was established as a biostratigraphic discipline, and studies of the dinoflagellate stratigraphy of the Middle and Upper Jurassic were undertaken in East Greenland by Piasecki $(1981,1996)$, Poulsen (1985), Smelror (1988), Milner \& Piasecki (1996) and Larsen et al. (2003).

\section{Geological setting}

The Jurassic of Jameson Land forms part of a several kilometre-thick sedimentary succession in the Jameson Land Basin. A short outline of the geological setting is presented here; a more thorough description is presented in Bjerager et al. (2018, this volume).

The Jameson Land Basin is bounded to the east by the uplifted basement block of the Liverpool Land high and to the west along faults towards the Caledonian basement west of Hall Bredning (Figs 1,2); the basin is c. 150 $\mathrm{km}$ wide. Its northern boundary is less well constrained, but is probably situated in the transition area between Jameson Land and Traill Ø (Dam et al. 1995). To the south, beyond Scoresby Sund, the basin probably continues beneath the thick Palaeogene basalt cover, indicating the basin to be more than $200 \mathrm{~km}$ long in an $\mathrm{N}-\mathrm{S}$ direction (Figs 1,2). The basin is tilted, with strata dipping slightly towards the south-west. Upper Palaeozoic strata are thus exposed in the northern areas and progressively younger strata are preserved and exposed towards the south, so that the youngest unit, a lowermost Cretaceous incised valley fill (Hesteelv Formation), is exposed in a small area in southernmost Jameson Land (Fig. 2). However, Valanginian and Hauterivian-Barremian sedimentary rocks are exposed along the western basin margin of Milne Land (Piasecki 1979; Birkelund et al. 1984) and thick sedimentary successions have been recognised in geophysical data below the fjord of Scoresby Sund (Larsen \& Marcussen 1992). It is thus suggested that Cretaceous sedimentation continued in the southern part of the Jameson Land Basin maybe until the early Cenozoic; Paleocene sediments are recorded to underlie Palaeogene flood basalts south of Jameson Land (Nøhr-Hansen \& Piasecki 2002). The location of the Blokelv-1 drill site was chosen with the objective of studying the inferred 
Fig. 4. Core piece viewed from the side showing a cross-section of a strongly ribbed ammonite forming a characteristic crenulated bedding plane (arrow). Core diameter: $56 \mathrm{~mm}$.

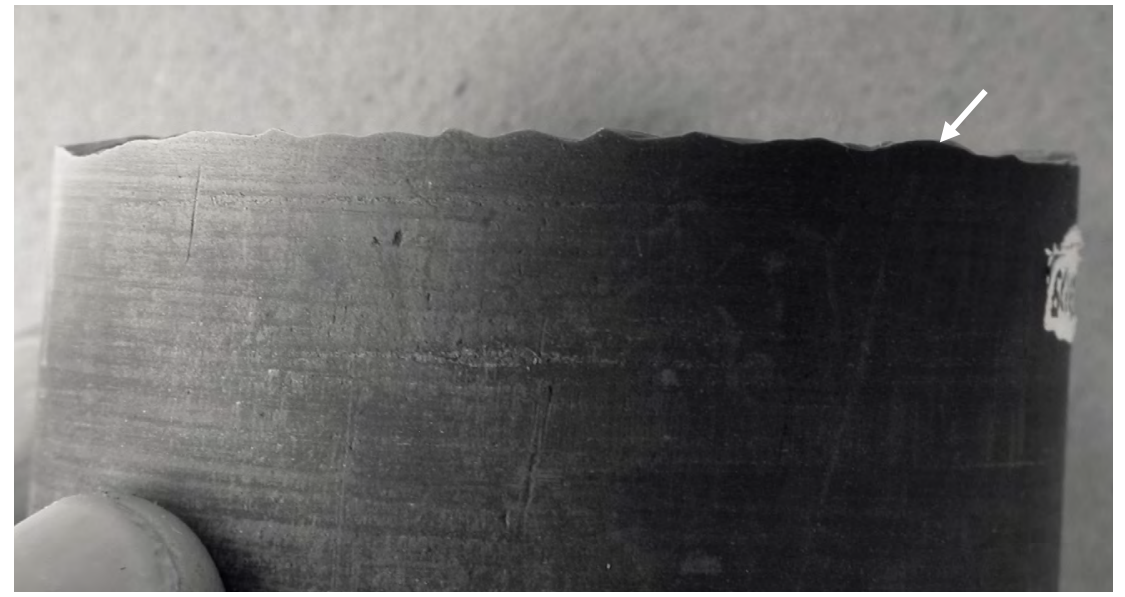

optimum source-rock interval, i.e. the thickest and most organic-rich mudstone section, which was expected to be found in the deepest, axial part of the basin. The site location at Blokelv guaranteed the presence of the Katedralen Member, and by starting the borehole near the base of the Sjællands Elv Member, it was ensured that the borehole would include the uppermost part of the Katedralen Member which had been poorly sampled in previous drilling campaigns (see Bjerager et al. 2018, this volume).

\section{Material and methods}

Core material is housed at GEUS. Figured ammonites are assigned with MGUH numbers (31799-31821) and are stored in the collections of the Geological Museum of Copenhagen (Natural History Museum of Denmark).

\section{Ammonites}

The poor exposures of the Hareelv Formation around the drill site at Blokelv are characterised by a lack of ammonites. During the 2008 drilling operation, attempts to collect and sample ammonites in the vicinity of the drill site were unsuccessful. During drilling, a few ammonites were noted in the core. In the laboratory, the core was searched systematically revealing a large number of ammonite-bearing intervals. The uppermost ammonite occurrence in the core is at a stratigraphic level well below that of the rocks exposed in the surrounding area, which might explain the unsuccessful search for ammonites at outcrop. The mudstones in the uppermost part of the core are less consolidated than in the lower levels of the core, however, and therefore the ammonite preservation potential is markedly lower. The lack of ammonites detected in the upper part of the core thus does not necessarily reflect an interval that was initially barren of ammonites.

Ammonites in the mudstones of the Blokelv core are flattened impressions with the shell material dissolved; the impressions are generally well-preserved, sometimes excellently preserved. Fragments of ammonites are common. Most ammonites are cut by the drill and therefore are not complete. However, a relatively large number of small complete ammonites are present.

The laminated mudstones split naturally along bedding-planes and particularly well along planes where ammonite impressions weaken the bedding. Bedding surfaces that were split open during coring or core management, were systematically inspected for macrofossils. In continuous, unbroken core sections, ammonites are sometimes visible in cross-section, since the relief of the ribbing forms a characteristic crenulated pattern; such core pieces were carefully split with hammer and chisel for inspection (Fig. 4).

A total of 42 levels with ammonites were recorded in the interval between core depths $213.84 \mathrm{~m}$ and $81.93 \mathrm{~m}-$ i.e. exclusively in the Katedralen Member of the Hareelv Formation. Additional levels with ammonite fragments were observed, but were not considered of biostratigraphic importance due to poor preservation, and were not sampled.

Ammonites in the Blokelv-1 core have been mostly identified by comparison with key taxonomic literature on East Greenland ammonites (Spath 1935, 1936; Sykes \& Surlyk 1976; Sykes \& Callomon 1979; Callomon 1985). The ammonite zonation for the OxfordianVolgian interval (Fig. 5) was established by Surlyk et al. 


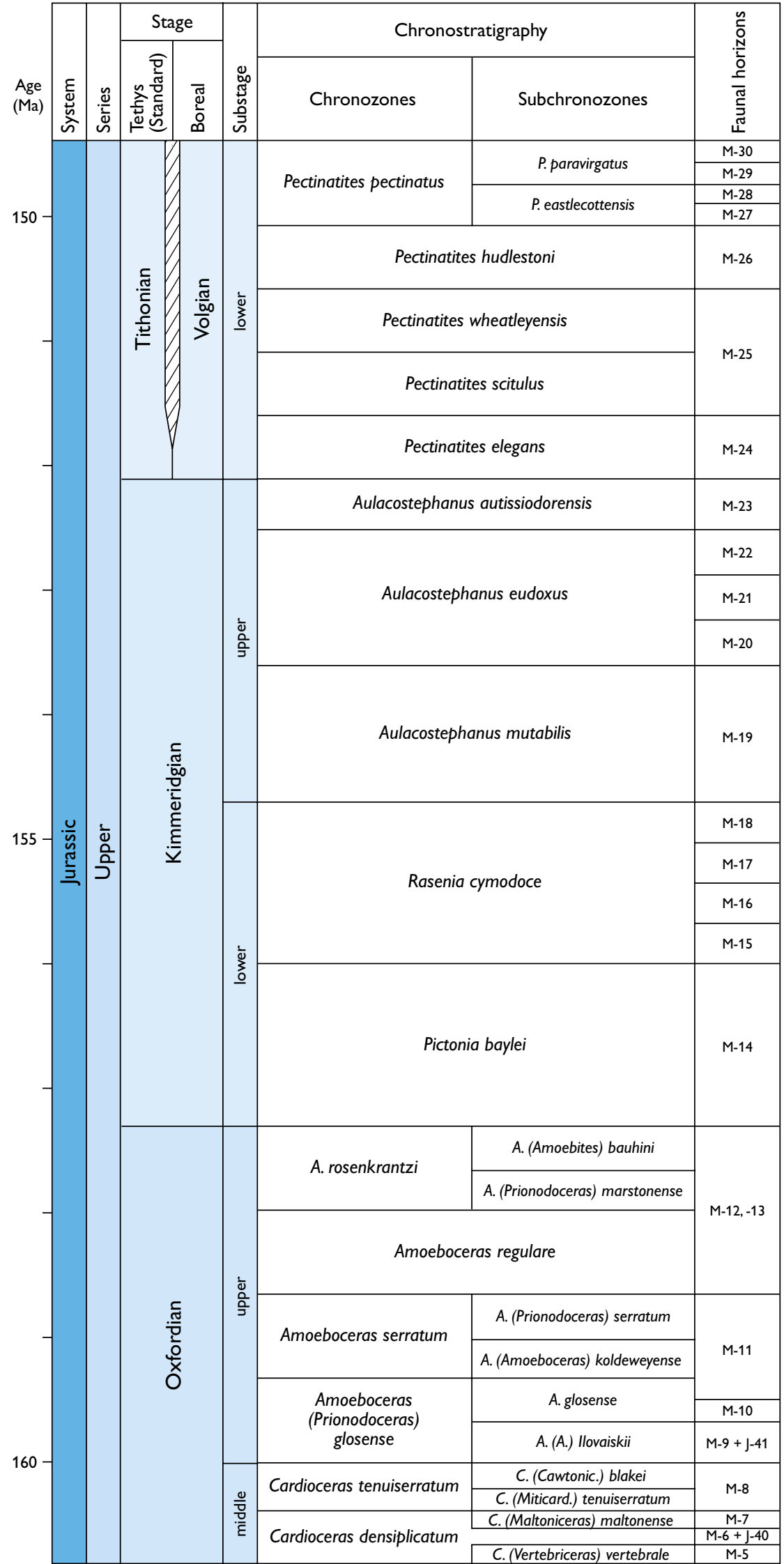

Fig. 5. Upper Jurassic (middle Oxfordian - lower Volgian) ammonite chronozone scheme for East and North-East Greenland. The vertical scale follows the geochronology of Gradstein et al. (2012). The chronozone breakdown is based on Surlyk (1978, 1991), Sykes \& Callomon (1979), Callomon \& Birkelund (1980, 1982), Birkelund et al. (1984) and Birkelund \& Callomon (1985). 

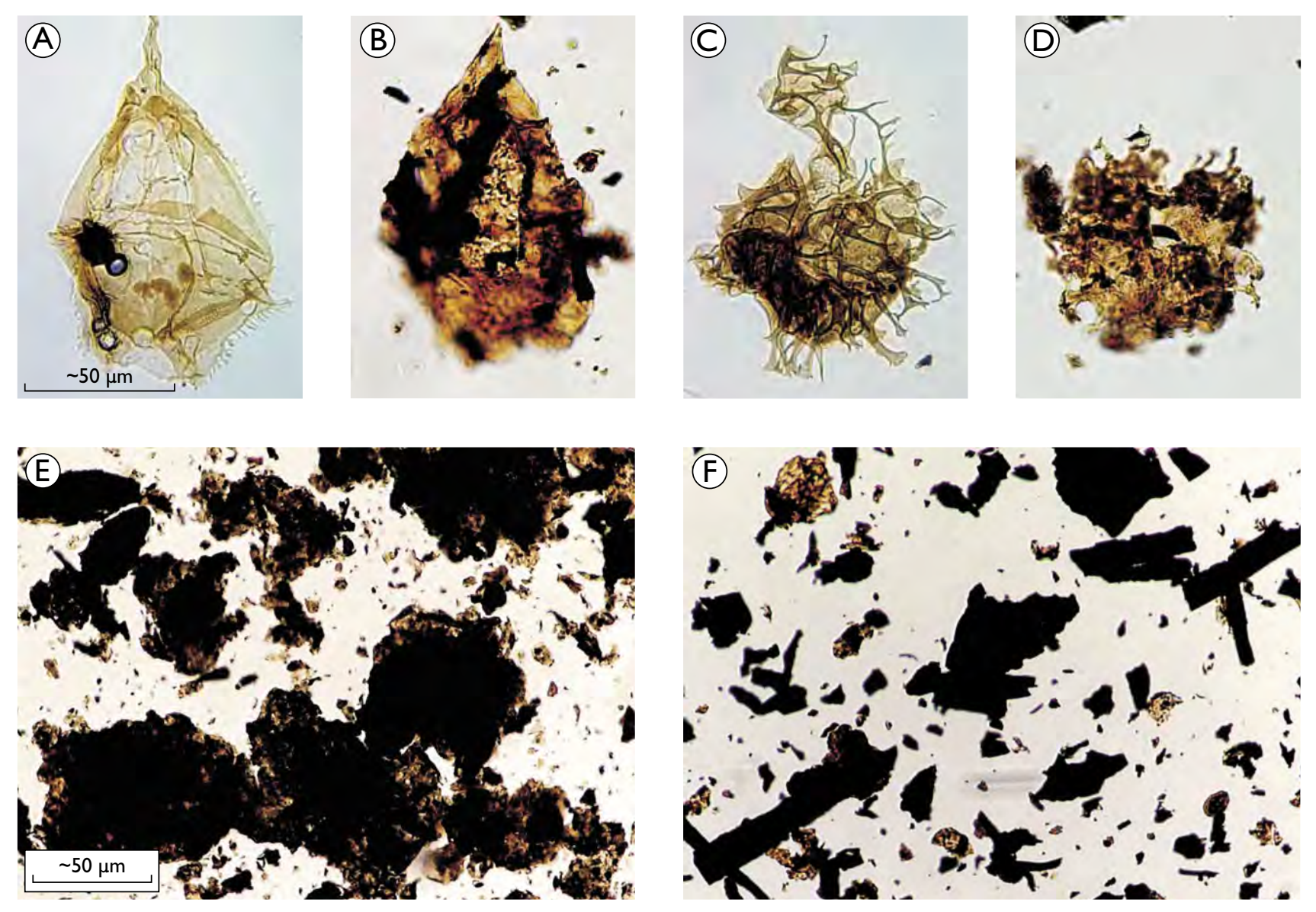

Fig. 6. A-D: Preservation of earliest Kimmeridgian (P. baylei Chronozone) fossil dinoflagellate cysts in the Blokelv-1 core (B, D; core depth $102.06 \mathrm{~m}$ ) compared with contemporaneous specimens of the same species from outcrop material from Milne Land (A, C; Kap Leslie Formation (Bays Elv Member), GGU 245830). A, B: Gonyaulacysta jurassica; C, D: Taeniophora sp.; the scale-bar in A is applicable to A-D. E, F: Two contrasting palynomorph assemblages from the Hareelv Formation in Blokelv-1; the scale-bar in E is also applicable to F. E: Assemblage dominated by marine organic matter, particularly amorphous organic material (AOM), sample $232.05 \mathrm{~m}$. F: Assemblage rich in black woody material, sample $17.00 \mathrm{~m}$.

(1973), Surlyk (1978), Callomon \& Birkelund (1980, 1982), Birkelund et al. (1984), Birkelund \& Callomon (1985) and summarised in Surlyk (1991, fig. 6); it was recently reviewed by Kelly et al. (2015).

\section{Dinoflagellate cysts}

Fifty-eight mudstone samples were collected from the core for palynological analysis and processed using standard preparation techniques in the Stratigraphic Laboratory at GEUS. The preparation process includes treatment with acids $\left(\mathrm{HCl}, \mathrm{HF}, \mathrm{HNO}_{3}\right)$ and filtering with $20 \mu \mathrm{m}$ filters. This treatment removes carbonates and silicates (clay, silt and sand) from the samples and the remaining organic sedimentary material is resistant to the acids. The amorphous organic material from the mudstone samples is highly resistant to this preparation such that repeated oxidation, extended ultrasonic treatment, washing in potassium hydroxide and filtering were necessary to recover at least some identifiable dinoflagellate cysts. The organic residue was mounted in glycerinegelatine on glass microscope slides for visual analysis by light microscopy.

Due to inadequate break-down and removal of the amorphous organic matter in most samples from the core, the record of dinoflagellate cysts is sporadic and productive samples are randomly distributed up the core section. Furthermore, the identification of species is hampered by the high content of amorphous organic matter (Fig. 6). The dinoflagellates are also strongly corroded and badly preserved, and thin-walled specimens 


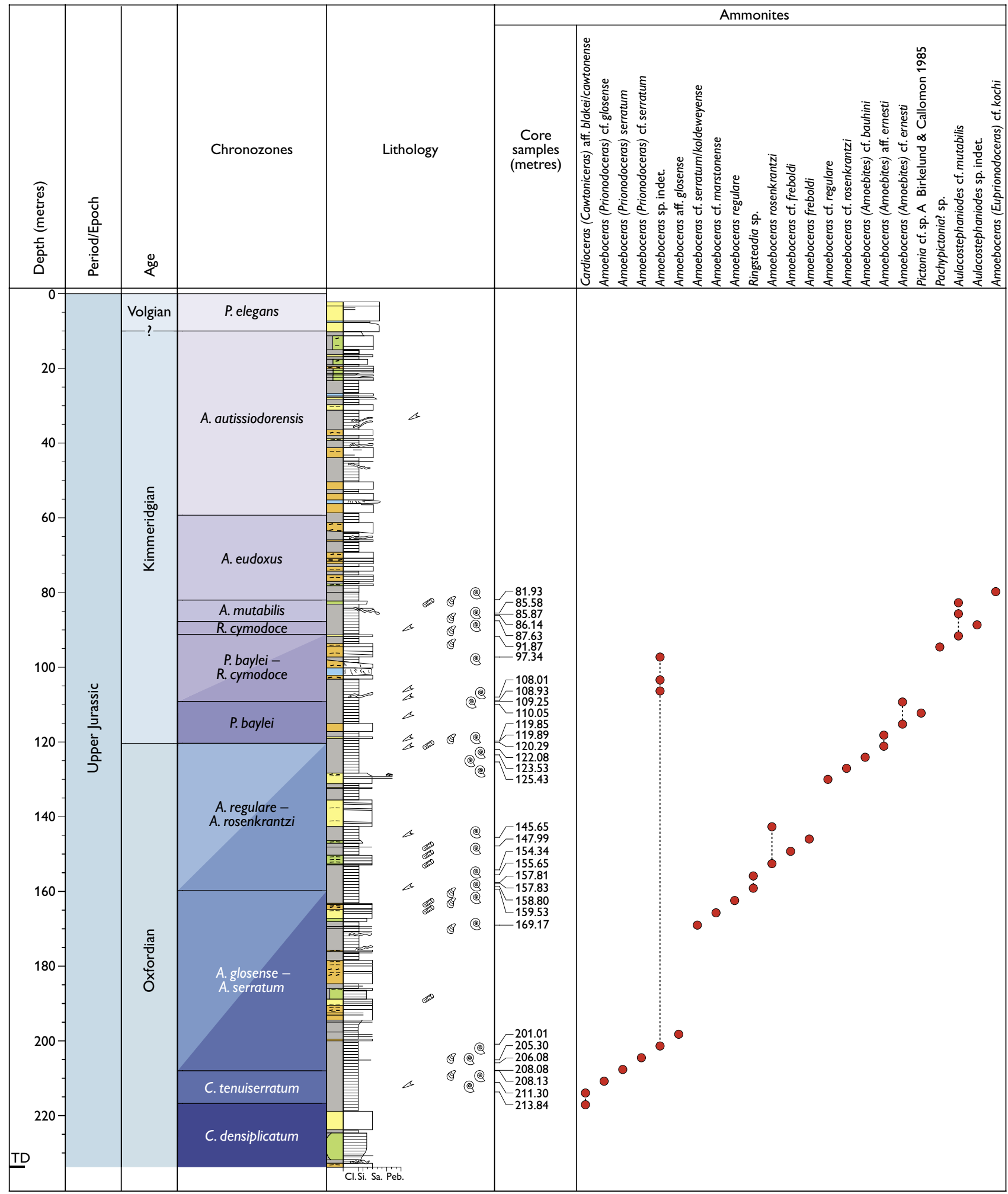

Fig. 7. Chart showing the stratigraphic distribution of ammonites in the Blokelv-1 core. For lithological legend, see Fig. 3. Note that focus is on displaying the relative succession of the individual taxa; where occurrences are closely spaced, the expanded sample position shown in the depth column is utilised in the distribution chart. 
may also be degraded due to heavy oxidation during preparation in the laboratory. Despite these setbacks, a number of important stratigraphic events can be recognised, especially when based on robust and abundant species. In view of the preservation and processing problems outlined above, semi-quantitative palynological analysis was considered to lack statistical significance and thus was not employed.

In Northwest Europe, Jurassic dinoflagellate biostratigraphy has been correlated to a Subboreal-Boreal ammonite zonation (e.g. Woollam \& Riding 1983; Riding \& Thomas 1992). However, the northward continuation of the Jurassic seaway (Ziegler 1982) from warm Tethyan to Boreal and possible Arctic environments resulted in stratigraphic variations in the first and last occurrences of the dinoflagellate species at different latitudes. The ammonite stratigraphy in East Greenland clearly illustrates the interaction of Subboreal and Boreal faunas (Callomon 1993; Callomon \& Birkelund 1982), and the increasing Boreal affinities towards the north are clearly demonstrated in the ammonite and dinoflagellate assemblages recorded from northern Norway (Wierzbowski $e t$ al. 2002), the Wandel Sea Basin, North Greenland (Håkansson et al. 1981) and Svalbard (Århus 1988).

\section{Other fossil groups}

In addition to ammonites, macrofossils in the core include belemnites, represented by rostra (few) and Onychites (arm hooks from belemnite cephalopods), bivalves and rare vertebrate remains (bone fragments and teeth).

Mudstones were sampled for microfossil and nannofossil analysis at three levels (core depths: $206 \mathrm{~m}, 198$ $\mathrm{m}, 190 \mathrm{~m}$ ), but neither foraminifers nor coccoliths were recovered (E. Sheldon, personal communication 2009). The apparent absence of calcareous microscopic fossils in the Blokelv-1 core is probably a function of dissolution as a result of the high content of pyrite and the consequent acidic conditions in the sediment.

\section{Stratigraphic methods}

\section{Boreal vs Tethyan stage nomenclature}

Due to marked faunal provincialism, the uppermost Jurassic - lowermost Cretaceous interval is commonly subdivided differently in the Tethyan and Boreal Realms (Fig. 4; see discussion in Zeiss 2003; Surlyk 2003). This pres- ently unresolved and controversial subject will not be considered further here; the Boreal subdivision (Kimmeridgian-Volgian-Ryazanian) has been routinely applied in East and North-East Greenland, and is adopted in this study and parallel studies in North-East Greenland.

\section{Ammonite chronozones}

An additional area of debate amongst ammonite palaeontologists/stratigraphers in particular concerns the definitions of, and relationships between, chronozones, standard zones and biozones (see Callomon 2003; Page 2003; Zeiss 2003). Certain schools consider the Jurassic ammonite stratigraphic record to be so highly resolved and well-studied as to define discrete chronostratigraphic units, variably termed chronozones or standard zones. Such rock units, in principle, represent a period of time that can also be recognised using fossil groups other than ammonites. This stratigraphic concept has been widely applied in East Greenland (Piasecki et al. 2004a, 2004b; Piasecki \& Stemmerik 2004; Vosgerau et al. 2004). In Milne Land, in particular, the detailed Upper Jurassic ammonite chronozone classification has been integrated with the dinoflagellate record (e.g. Piasecki 1981; Larsen et al. 2003). Dinoflagellate events and ranges are closely merged with the ammonite faunas and zonation, the former commonly being based on sample material derived directly from ammonite specimens (e.g. Larsen et al. 2003; Piasecki et al. 2004b). Rather than developing a local palynological biozonation for Milne Land, the dinoflagellate data were related directly to the ammonite chronozones (Piasecki 1981; Larsen et al. 2003). This approach is maintained in this study; given the reference chrono-zonation of the Milne Land succession, the ammonite and palynological dataset presented here permits the breakdown of the Blokelv core section into ammonite chronozones. It should be noted that a chronozone may be recognized based on either key ammonites or dinoflagellates, or on a combination of both groups.

\section{Integrated ammonite and dino- flagellate stratigraphy}

The biostratigraphic subdivision of the Blokelv- 1 core is described from total depth (TD) at $233.80 \mathrm{~m}$ and upwards. The recorded ammonite levels are listed in Table 1 and illustrated in a stratigraphic distribution chart (Fig. 7). The dinoflagellate records and events are illustrated in a stratigraphic distribution chart (Fig. 8). 
Table 1. Core depth and stratigraphy of ammonites in Blokelv-1

\begin{tabular}{|c|c|c|c|c|c|}
\hline $\begin{array}{l}\text { Depth } \\
\text { (m) }\end{array}$ & Ammonite taxon & Figure & $\begin{array}{c}\text { Faunal } \\
\text { horizon }\end{array}$ & Chronozone & $\begin{array}{c}\text { MGUH } \\
\text { no. }\end{array}$ \\
\hline 81.93 & Amoeboceras (Euprionodoceras) cf. kochi Spath & Fig. 10l & M-20 & A. eudoxus & 31821 \\
\hline 85.58 & Aulacostephanoides cf. mutabilis (Sowerby) & & M-19 & A. mutabilis & 31820 \\
\hline 85.87 & Aulacostephanoides cf. mutabilis (Sowerby) & Fig. 10H & M-19 & & \\
\hline 86.14 & Aulacostephanoides sp. indet. & & & & \\
\hline 87.63 & Aulacostephaniodes cf. mutabilis (Sowerby) & Fig. 10G & M-19 & A. mutabilis & 31819 \\
\hline 91.87 & Pachypictonia? sp. & Fig. 10F & M-16 & R. cymodoce & 31818 \\
\hline 97.34 & Amoeboceras sp. indet. & & & & \\
\hline 108.01 & Amoeboceras sp. indet. & & & & \\
\hline 108.93 & Amoeboceras sp. indet. & & & & \\
\hline 109.25 & Amoeboceras (Amoebites) cf. ernsti (Fischer) & Fig. 10E & M-14 & P. baylei & 31817 \\
\hline 110.05 & Pictonia cf. sp. A. Birkelund \& Callomon 1985 & Fig. 10D & M-14 & P. baylei & 31816 \\
\hline 119.85 & Amoeboceras (Amoebites) cf. ernesti (Fischer) & Fig. $10 \mathrm{C}$ & M-14 & P. baylei & 31815 \\
\hline 119.89 & Amoeboceras (Amoebites) aff. ernesti (Fischer) & Fig. 10B & M-14 & P. baylei & 31814 \\
\hline 120.29 & Amoeboceras (Amoebites) aff. ernesti (Fischer) & Fig. $10 \mathrm{~A}$ & M-14 & P. baylei & 31813 \\
\hline 122.08 & Amoeboceras (Amoebites) cf. bauhini (Oppel) & & $M-12,-13$ & A. regulare $-A$. rosenkrantzi & \\
\hline 123.53 & Amoeboceras cf. rosenkrantzi Spath & Fig. 9L & $M-12,-13$ & A. regulare $-A$. rosenkrantzi & 31812 \\
\hline 125.43 & Amoeboceras cf. regulare Spath & Fig. 9K & $M-12,-13$ & A. regulare $-A$. rosenkrantzi & 31811 \\
\hline 145.65 & Amoeboceras rosenkrantzi Spath & Fig. 9J & $M-12,-13$ & A. regulare $-A$. rosenkrantzi & 31810 \\
\hline 147.99 & Amoeboceras freboldi Spath & Fig. 9l & $M-12,-13$ & A. regulare $-A$. rosenkrantzi & 31809 \\
\hline 154.34 & Amoeboceras cf. freboldi Spath & & $M-12,-13$ & A. regulare $-A$. rosenkrantzi & \\
\hline 155.65 & Amoeboceras rosenkrantzi Spath & Fig. 9H & $M-12,-13$ & A. regulare $-A$. rosenkrantzi & 31808 \\
\hline 157.81 & Ringsteadia sp. & & $M-12,-13$ & A. regulare $-A$. rosenkrantzi & \\
\hline 157.83 & Ringsteadia sp. & & $M-12,-13$ & A. regulare $-A$. rosenkrantzi & \\
\hline 158.80 & Amoeboceras regulare Spath & Fig. 9G & $M-12,-13$ & A. regulare $-A$. rosenkrantzi & 31807 \\
\hline 159.53 & Amoeboceras cf. marstonense Spath & Fig. $9 \mathrm{~F}$ & $M-12,-13$ & A. regulare $-A$. rosenkrantzi & 31806 \\
\hline 169.17 & Amoeboceras cf. serratum (Sowerby) or koldeweyense Sykes \& Callomon & Fig. 9E & M-11 & A. glosense $-A$. serratum & 31805 \\
\hline 201.01 & Amoeboceras aff. glosense (Bigot \& Brasil) & Fig. 9D & M-11 & A. glosense $-A$. serratum & 31804 \\
\hline 205.30 & Amoeboceras sp. indet. & & & & \\
\hline 206.08 & Amoeboceras (Prionodoceras) cf. serratum (Sowerby) & Fig. 9C & M-11 & A. glosense $-A$. serratum & 31803 \\
\hline 208.08 & Amoeboceras (Prionodoceras) serratum (Sowerby) & Fig. 9B & M-11 & A. glosense $-A$. serratum & 31802 \\
\hline 208.13 & Amoeboceras (Prionodoceras) cf. glosense (Bigot \& Brasil) & Fig. 9A & M-10, -11 & A. glosense - A. serratum & 31801 \\
\hline 211.30 & Cardioceras (Cawtoniceras) aff. blakei Spath or cawtonense (Blake \& Huddleston) & Fig. 8C, D & M-8 & C. tenuiserratum & 31800 \\
\hline 213.84 & Cardioceras (Cawtoniceras) aff. blakei Spath or cawtonense (Blake \& Huddleston) & Fig. $8 \mathrm{~A}, \mathrm{~B}$ & M-8 & C. tenuiserratum & 31799 \\
\hline
\end{tabular}

\section{C. densiplicatum Chronozone (233.80 (TD) - $217.00 \mathrm{~m})$}

Ammonites were not recorded in this chronozone and its recognition is based on its dinoflagellate record. The lower boundary is placed arbitrarily at the base of the cored section (TD), exactly $1 \mathrm{~m}$ below the lowermost sample containing palynomorphs $(232.80 \mathrm{~m})$.

\section{Dinoflagellates}

Assemblage. A poor assemblage characterised by the highest occurrences of species that generally show last occurrences in the Oxfordian: Kalyptea spp., Nannoceratopsis pellucida, Rigaudella aemula, Trichodinium scarburghense and Wanaea spp.

Stratigraphy. The last occurrence of Trichodinium scarburghense $(232.80 \mathrm{~m})$, Rigaudella aemula $(224.80 \mathrm{~m})$ and the maximum occurrence of Kalyptea spp. $(218.40 \mathrm{~m})$ are all events that were reported in Milne Land in the upper $C$. densiplicatum Chronozone between ammonite faunal horizons M-6 and M-7 (Piasecki 1996).

Age

Middle Oxfordian, Late Jurassic.

\section{C. tenuiserratum Chronozone (217.00-208.13 m)}

The lower boundary of the chronozone at $217 \mathrm{~m}$ is placed arbitrarily between the highest occurrence of the Kalyptea spp. acme event at $218.40 \mathrm{~m}$ (in the under-lying $C$. densiplicatum Chronozone) and the lowest occurence of the ammonite $C$. (C.) aff. blakei Spath 1935 or cawtonense (Blake \& Huddleston 1877) at $213.84 \mathrm{~m}$. 


\section{Ammonites}

An ammonite specimen at $213.84 \mathrm{~m}$ is a well-preserved and complete specimen with a relatively narrow umbilicus. It has 17 primary ribs, which on the last whorl develop from fine, slightly bullate to markedly thick, slightly sinuous, bullate ribs. The primaries bifurcate high on the sides and with intercalatories result in 45-50 secondaries. (Figs 9A, B). It resembles $C$. (C.) blakei in ribbing density and ribbing sinuousity but is ribbed in the umbilicus and thus differs from the smooth umbilicus in a specimen figured by Sykes \& Callomon (1979, plate 113, fig. 3). It also resembles $C$. (Cawtoniceras) cawtonense (e.g. Callomon 1985, text fig. $8 \mathrm{u}$ ) which has a ribbed umbilicus, but with straight ribs.

An ammonite specimen sampled slightly higher, at $211.30 \mathrm{~m}$, is a small juvenile with relatively weak ribbing on the sides becoming stronger towards the ventrolateral margin (Figs 9C, D). The ribs are sinuous and resemble C. blakei. The size difference, however, does not allow direct comparison. Both specimens are referred to Cardioceras (Cawtoniceras) aff. blakei or C. (C.) cawtonense and indicate the faunal horizon $\mathrm{M}-8$, which can be referred to a level in the upper middle Oxfordian C. tenuisserratum Chronozone (Fig. 5).

\section{Dinoflagellates}

Assemblage. The recorded dinoflagellate assemblage is poor, including Kalyptea spp., Pareodinia spp. (e.g. P. prologata) and Rhyncodiniopsis cladophora.

Stratigraphy. The C. tenuiserratum Chronozone is indicated by the last occurrence of Pareodinia prologata at $209.80 \mathrm{~m}$ (Riding \& Thomas 1992).

Age

Middle Oxfordian, Late Jurassic.

\section{A. glosense $-A$. serratum Chronozones (208.13-159.53 m)}

Ammonite occurrences are restricted to the lower part of this interval and the dinoflagellate cyst assemblages are generally poor. The interval is thus referred undifferentiated to the $A$. glosense - A. serratum Chronozones. The lower boundary is placed at the lowest occurrence of $A$. (P.) cf. glosense at $208.13 \mathrm{~m}$.

\section{Ammonites}

A well-preserved, large (size of complete specimen estimated at $82 \mathrm{~mm}$ ) ammonite at a depth of $208.13 \mathrm{~m}$ has rursiradiate ribs developed on the umbilical wall, which curve when crossing the umbilical shoulder and become straight and rectiradiate on the sides (Fig. 10A). The primary ribs occasionally bifurcate in the upper part of the flank on the second last whorl. Fifteen primaries can be counted on half a whorl, suggesting 30 primaries per whorl. Ribbing density increases in the last part of the body chamber, with 10 primaries counted on a quarter of a whorl. The ribs bend strongly forward when crossing the ventral shoulder. The keel appears high. It represents Amoeboceras (Prionodoceras) cf. glosense (Bigot $\&$ Brasil 1904), indicating the faunal horizons M-10 or M-11, since this species is known to occur in both horizons. These two faunal horizons represent the $A$. serratum Chronozone and the uppermost part of the underlying $A$. glosense Chronozone in Greenland. The specimen probably indicates the lower part of that interval since ammonites in the overlying interval, up to $169.67 \mathrm{~m}$, include specimens indicative of the faunal horizon M-11.

A. (Prionodoceras) serratum (Sowerby 1813) is large, with dense, straight and strong prorsiradiate ribs with umbilical, middle and ventrolateral tubercles on the inner whorls, and primaries that bifurcate just below the ventral shoulder ( $208.08 \mathrm{~m}$, Fig. 10B). The ribbing is less strong in the outer whorls, leaving only faint lirae or growth lines. A specimen at $206.08 \mathrm{~m}$ that is also characterised by lirae and sometimes by flared ribs is referred to A. (P.) cf. serratum (Fig. 10C).

A well-preserved microconch with lappet at $201.01 \mathrm{~m}$ (Fig. 10D) has dense, fine ribbing with backwards-curving primaries on the umbilical shoulder, then becoming straight or gently concave on the flanks, then projected high on the flank and when crossing the ventral shoulder. Secondaries appear high on the sides. The ribbing resembles that of a densely ribbed variety of $A$. glosense figured in Sykes \& Callomon (1979, plate 116, fig. 2) but differs in being much larger than adult microconchs of that species. It is thus referred here to Amoeboceras aff. glosense.

The highest ammonite indicative of the $A$. glosense A. serratum Chronozone is found at a depth of $169.17 \mathrm{~m}$ (Fig. 10E). The specimen is overprinted by trace fossils, but is otherwise well-preserved. It appears to be rather weakly ornamented, but on the last whorl relatively strong, curved tuberculate ribs on the umbilical shoulder are developed; it is otherwise almost smooth on the sides except for faint lirae or growth lines and relatively strong, well-spaced, bullae on the mid-flank. Forward-curving 


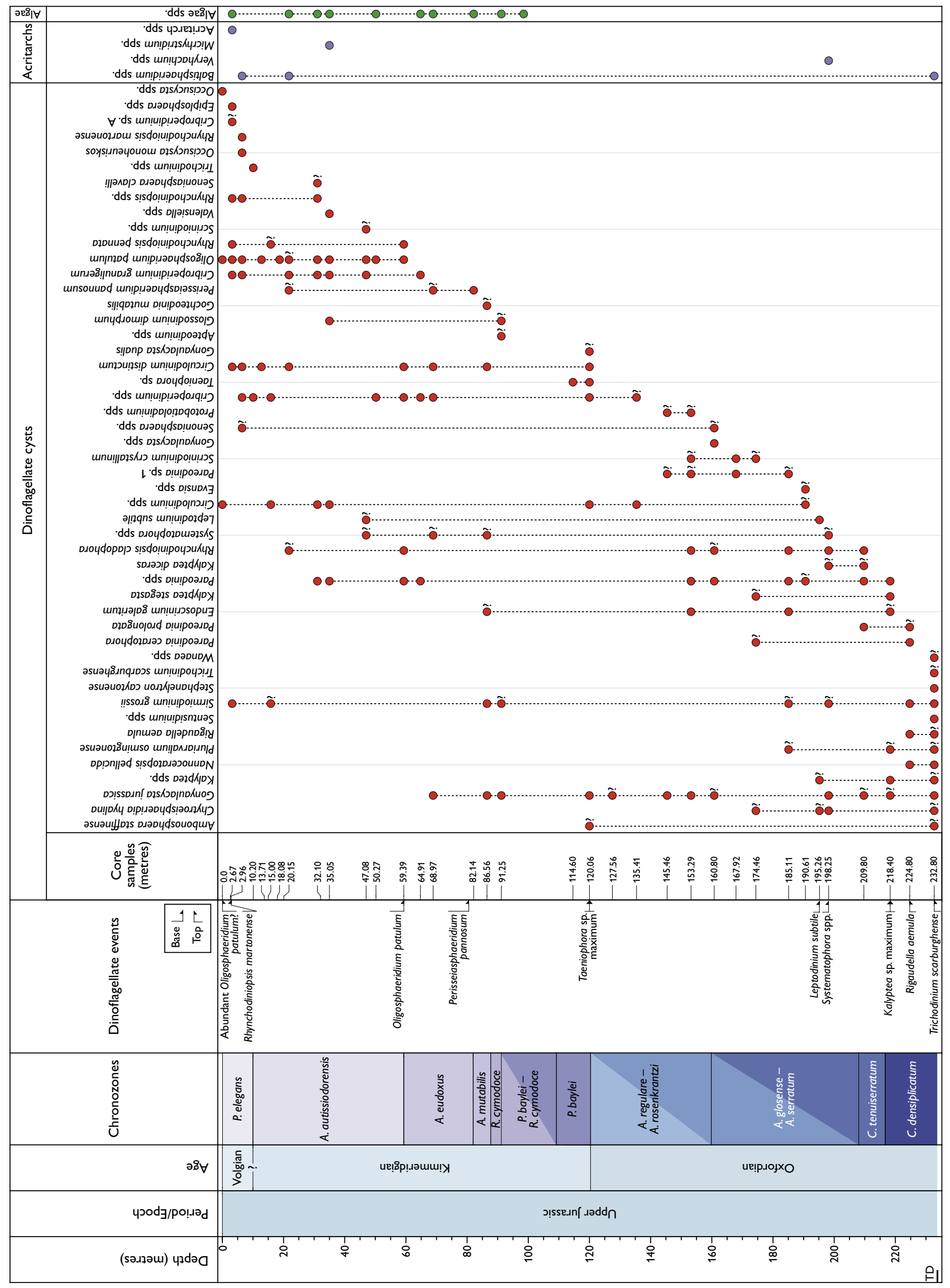


Fig. 9. Ammonites from the C. tenuiserratum Chronozone: Cardioceras (Cawtoniceras) aff. blakei Spath 1935 or cawtonense (Blake \& Huddleston 1877). A, B: MGUH 31799 (ex GEUS 511101433) from level $213.84 \mathrm{~m}$ (A: natural size. B: ×2). C, D: MGUH 31800 (ex GEUS 511101-432) from level $211.30 \mathrm{~m}$ (C: natural size. D: $\times 2$ ).
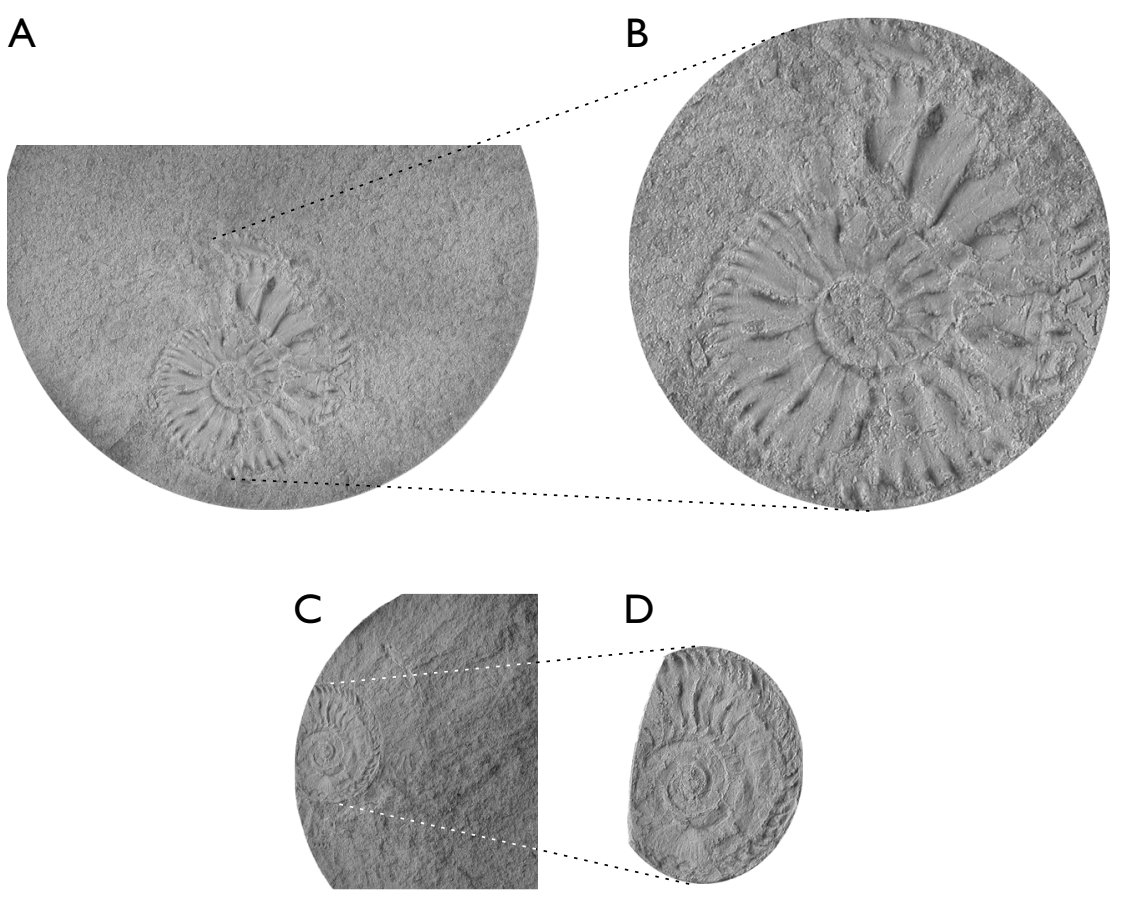

Age

Late Oxfordian, Late Jurassic.

\section{A. regulare $-A$. rosenkrantzi Chronozones (159.53-120.29 m)}

Ammonites are relatively common in the fine-grained parts of the interval, whereas dinoflagellate cysts are rare. The lower boundary is placed at the sole occurrence of the ammonite $A$. cf. marstonense at $159.53 \mathrm{~m}$.

\section{Ammonites}

Ammonites of the $A$. rosenkrantzi - $A$. regulare Chronozones are found between $159.53 \mathrm{~m}$ and $123.53 \mathrm{~m}$. The lowermost $(159.53 \mathrm{~m}$, Fig. 10F) is a small, relatively involute, densely ribbed specimen with backward curving secondaries; this is characteristic of $A$. marstonense Spath 1935. The present specimen is, with some caution, referred to $A$. cf. marstonense, since its small size makes direct comparison with previously figured specimens difficult.

A small part of a well-preserved, relatively large specimen occurs at a depth of $158.80 \mathrm{~m}$ (Fig. 10G). It has straight, densely and regularly spaced ribs, primaries and intercalatories, which curve strongly forward on the ventral shoulder, but disappear and leave the relatively high
Facingpage:

Fig. 8. Chart showing the stratigraphic distribution of palynomorphs in the Blokelv-1 core. Note that focus is on displaying the relative succession of the individual taxa; where samples are closely spaced, the expanded sample position shown in the depth column is utilised in the distribution chart. The samples indicated with question marks are those in which identifications are tentative due to poor preservation. 
keel with smooth sides, whereas the outer margin of the keel is finely serrated. It belongs to $A$. regulare Spath 1935. Another specimen (125.43 m, Fig. 10K), small and less well-preserved but apparently also with dense ribbing that is strongly projected at the ventral shoulder, resembles a specimen figured and referred to $A$. cf. regulare by Sykes \& Callomon (1979, plate 118, fig. 4).

Ammonite fragments with prorsiradiate concave ribbing with the primaries dividing rather high on the flanks, middle flank or higher, are considered to belong to the genus Ringsteadia sp. (157.83 and $157.81 \mathrm{~m}$; not figured).

A fragment (c. a quarter of a whorl) of an ammonite is preserved at $155.65 \mathrm{~m}$ and a faint imprint of another at a depth of $145.65 \mathrm{~m}$ (Figs 10H, J, respectively). They are involute, strongly ribbed with fairly coarse, straight to slightly curved ribs on the flanks. Weak tubercles may develop at the mid-flank, whereas all ribs become tuberculate at the ventrolateral shoulder, where they curve forward (moderately to strongly) on the venter. They represent $A$. rosenkrantzi Spath 1935. Another less wellpreserved specimen at $123.53 \mathrm{~m}$ is referred to $A$. cf. rosenkrantzi (Fig. 10L).

A medium-large specimen is preserved in part at $147.99 \mathrm{~m}$ (Fig. 10I). The inner whorls are densely and finely ribbed, whereas the outer whorl is characterised by fairly faint ribbing on the flank, but with strong bullate tubercles developed on the ventrolateral margin. It resembles closely the $A$. freboldi figured by Sykes \& Surlyk (1976, fig. 5f), and is referred to that species. Another less well-preserved specimen is more cautiously referred to as $A$. cf. freboldi ( $154.34 \mathrm{~m}$, not figured).

A specimen of Amoeboceras cf. baubini (Oppel 1863) is recorded at a depth of $122.08 \mathrm{~m}$ (not figured). It is crushed and poorly preserved. The ribbing is strong, interrupted by a smooth band two-thirds up the flank. Ribbing becomes strong again above the smooth band and persists to the venter, a characteristic of $A$. baubini. The preservation, however, only permits tentative identification.

The ammonite material within the interval thus indicates the undifferentiated faunal horizons M-12 to M-13 of Callomon \& Birkelund (1980; Fig. 4). In Britain, the ammonite $A$. regulare is known to range only to the top of the $A$. regulare Chronozone (Sykes \& Callomon 1979), suggesting that the boundary between the $A$. regulare and A. rosenkrantzi Chronozones may lie between $125.43 \mathrm{~m}$ and $123.53 \mathrm{~m}$ in the Blokelv- 1 core.

\section{Dinoflagellates}

Assemblage. A poor assemblage of Cribroperidinium spp., Endoscrinium galeritum, Gonyaulacysta jurassica, Pareodinia spp., Rhynchodiniopsis cladophora and Scriniodinium crystallinum.

Stratigraphy. Dinoflagellate cysts are very rare in this interval, combined with a low diversity of species. Impoverished assemblages are also recorded on Milne Land, possibly reflecting increased Boreal affinities in this interval (Sykes \& Callomon 1979). Similar impoverished assemblages are recorded to the north in Peary Land (Håkansson et al. 1981), Nordland, Norway (Wierzbowski et al. 2002) and Svalbard (Århus 1988). All species recorded from this interval have long ranges and cannot be referred to ammonite chronozones. The broad interpretation of the age based on palynology is middle to late Oxfordian.

\section{Age}

Late Oxfordian, Late Jurassic.

\section{Facingpage:}

Fig. 10. Ammonites from the $A$. glosense - A. serratum Chronozones interval and the $A$. regulare - $A$. rosenkrantzi Chronozones interval in the Blokelv-1 core; all figured at natural size.

A: Amoeboceras (Prionodoceras) cf. glosense (Bigot \& Brasil 1904), MGUH 31801 (ex GEUS 511101-426), core depth 208.13 m.

B: Amoeboceras (Prionodoceras) serratum (Sowerby 1813), MGUH 31802 (ex GEUS 511101-425), core depth $208.08 \mathrm{~m}$.

C: Amoeboceras (Prionodoceras) cf. serratum, MGUH 31804 (ex GEUS 511101-430), core depth $206.08 \mathrm{~m}$.

D: Amoeboceras aff. glosense, MGUH 31804 (ex GEUS 511101-431), core depth $201.01 \mathrm{~m}$.

E: A. cf. serratum or koldeweyense Sykes \& Callomon 1979, MGUH 31805 (ex GEUS 511101-424), core depth $169.17 \mathrm{~m}$.

F: Amoeboceras cf. marstonense Spath 1935, MGUH 31806 (ex GEUS 511101-739), core depth $159.53 \mathrm{~m}$.

G: Amoeboceras regulare Spath 1935, MGUH 31807 (ex GEUS 511101-457), core depth $158.80 \mathrm{~m}$.

H: Amoeboceras rosenkrantzi Spath 1935, MGUH 31808 (ex GEUS 511101-435), core depth $155.65 \mathrm{~m}$.

I: Amoeboceras freboldi Spath 1935, MGUH 31809 (ex GEUS 511101-434), core depth $147.99 \mathrm{~m}$.

J: Amoeboceras rosenkrantzi, MGUH 31810 (ex GEUS 511101-454), core depth $145.65 \mathrm{~m}$.

K: Amoeboceras cf. regulare, MGUH 31811 (ex GEUS 511101-451), core depth $125.43 \mathrm{~m}$.

L: Amoeboceras cf. rosenkrantzi, MGUH 31812 (ex GEUS 511101449), core depth $123.53 \mathrm{~m}$. 


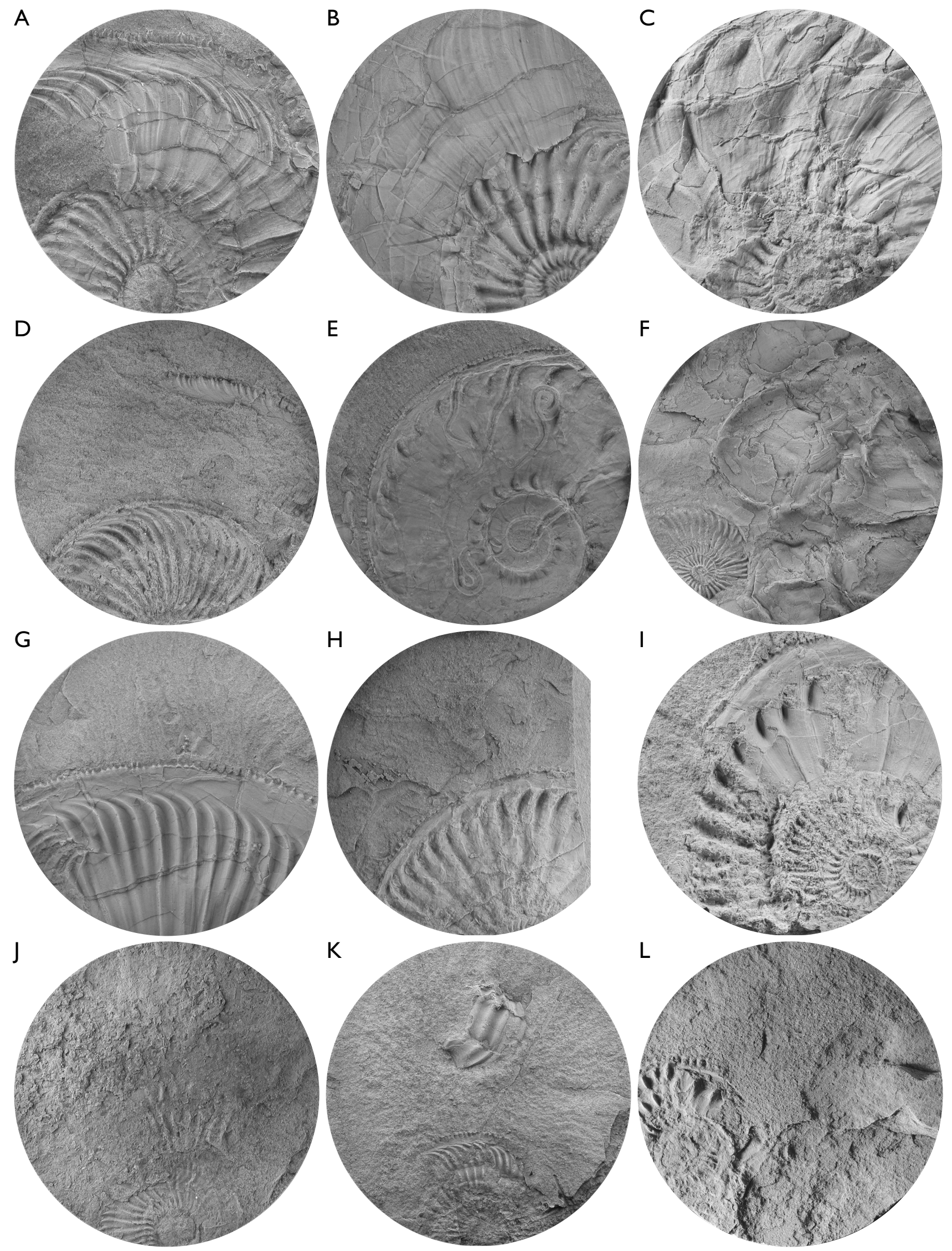




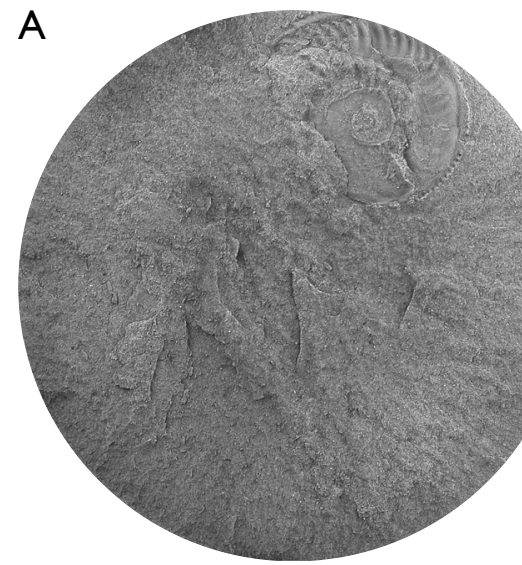

$\mathrm{D}$

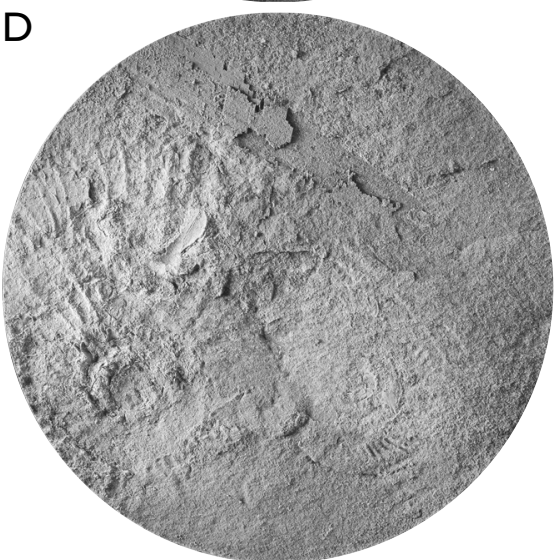

G

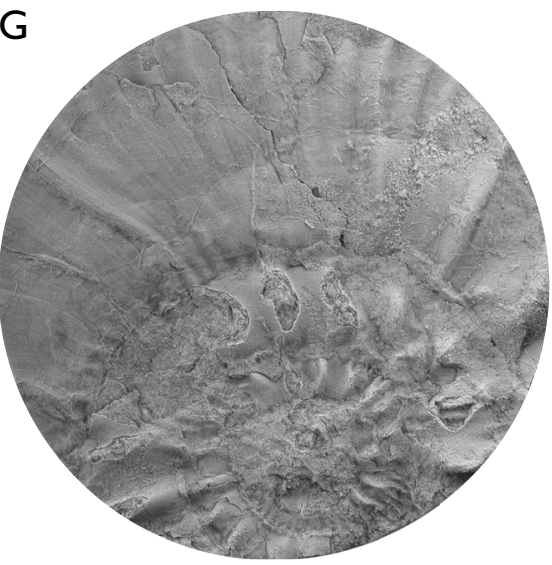

B

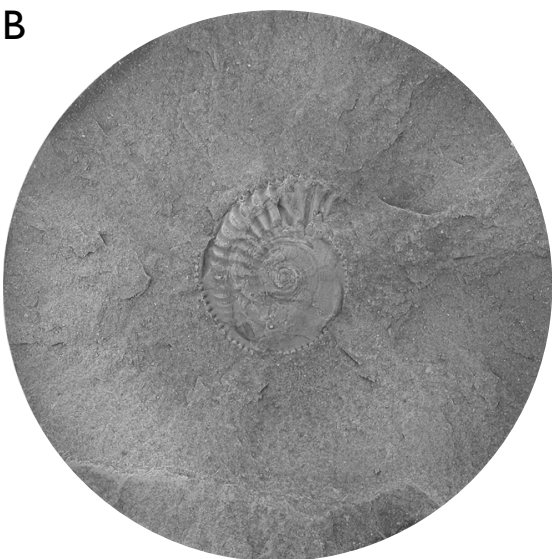

$E$

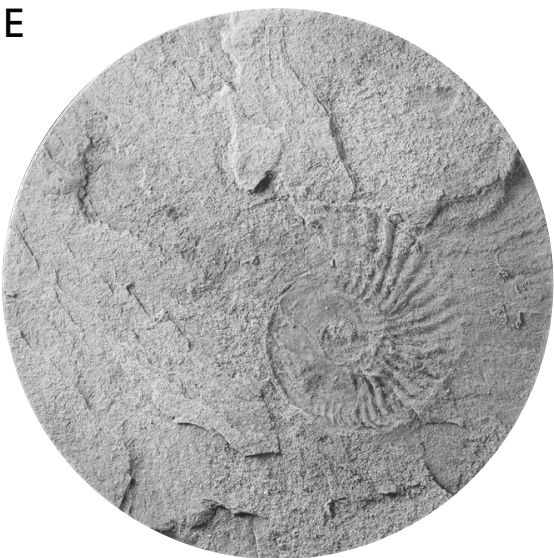

$\mathrm{H}$

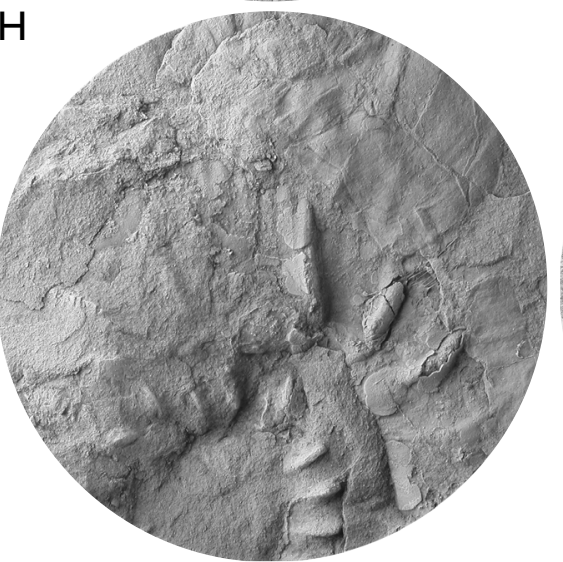

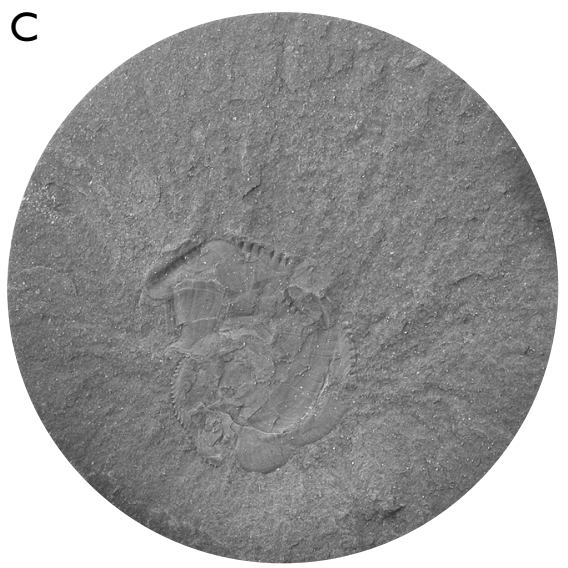

$\mathrm{F}$

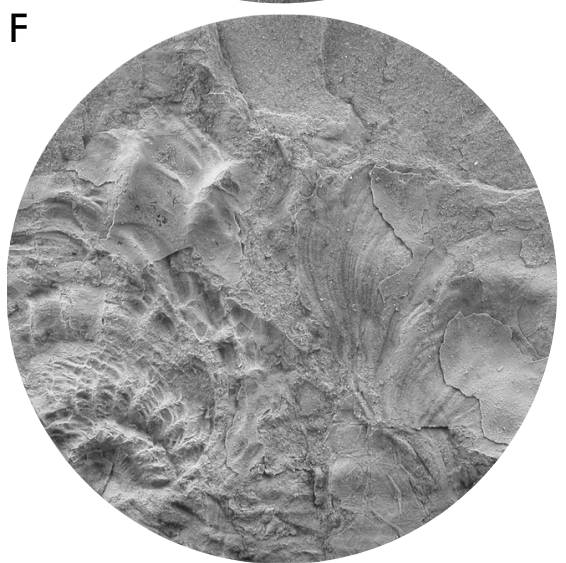

I

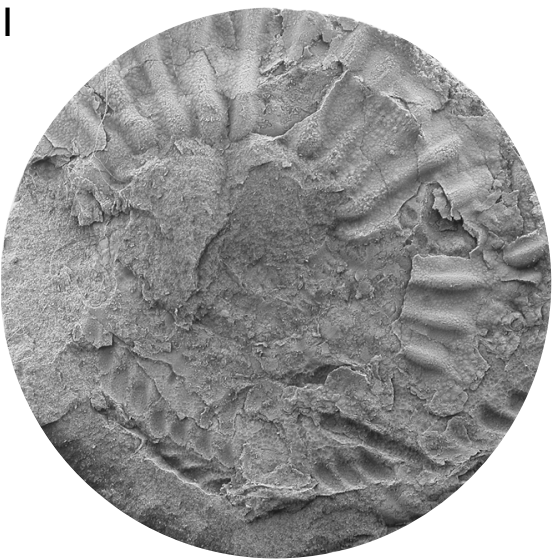

Fig. 11. Ammonites from the $P$. baylei Chronozone - A. eudoxus Chronozone interval in the Blokelv-1 core; all figured at natural size.

A, B: Amoeboceras (Amoebites) aff. ernesti (Fischer 1913). A: MGUH 31813 (ex GEUS 511101-446), core depth 120.29 m. B: MGUH 31814 (ex GEUS 511101-445), core depth $119.89 \mathrm{~m}$.

C, E: Amoeboceras (Amoebites) cf. ernesti. C: MGUH 31815 (ex GEUS 511101-444), core depth 119.85 m. E: MGUH 31817 (ex GEUS 551101417), core depth $109.25 \mathrm{~m}$.

D: Pictonia cf. sp. A Birkelund \& Callomon 1985, MGUH 31816 (ex GEUS 511101-412), core depth 110.05 m. F: Pachypictonia? sp., MGUH 31818 (ex GEUS 511101-420), core depth $91.87 \mathrm{~m}$.

G, H: Aulacostephaniodes cf. mutabilis (Sowerby 1823). G: MGUH 31819 (ex GEUS 511101-402), core depth 87.63 m. H: MGUH 31820 (ex GEUS 511101-407,) core depth $85.87 \mathrm{~m}$.

I: Amoeboceras (Euprionodoceras) cf. kochi Spath1935, MGUH 31821 (ex GEUS 511101-413), core depth 81.93 m. 


\section{P. baylei Chronozone (120.29-109.25 m)}

The base of the chronozone in the Blokelv-1 core is placed at the first stratigraphic occurrence of the ammonite Amoeboceras aff. ernesti at $120.29 \mathrm{~m}$.

\section{Ammonites}

In Greenland, the P. baylei Chronozone is represented by one faunal horizon, M-14 (Fig. 5). The presence of this horizon in the Blokelv-1 core is indicated by the occurrence of small Amoeboceras microconchs related to $A$. (Amoebites) ernesti (Fischer 1913) at four levels (120.29 m, $119.89 \mathrm{~m}, 119.85 \mathrm{~m}, 109.25 \mathrm{~m})$. They are characterised by smooth early whorls and isocostate ribbing (Figs $11 \mathrm{~A}-\mathrm{C}, \mathrm{E})$.

Within this interval characterised by $A$. ernesti, a faint imprint of a specimen of Pictonia was recorded at a depth of $110.05 \mathrm{~m}$ (Fig. 11D). It is evolute and relatively densely and delicately ribbed. The ribs appear to bifurcate high on the outer whorl leaving the bifurcation level hidden on earlier whorls. The ribs are slightly prorsiradiate and convex. The specimen closely resembles $P$. cf. sp. A as figured by Birkelund \& Callomon (1985, plate 11, fig. 3).

\section{Dinoflagellates}

Assemblage. A poor assemblage of common Taeniophora sp. (Fig. 6D) and rare Ambonosphaera staffinensis, Circulodinium spp. and Gonyaulacysta jurassica (Fig. 6B).

Stratigraphy. In Milne Land, the maximum abundance of Taeniophora sp. was recorded in the lower P. baylei Chronozone below ammonite faunal horizon M-14 (Piasecki 1996); this event is observed at $120.06 \mathrm{~m}$ in the Blokelv-1 core section.

Age

Earliest Kimmeridgian, Late Jurassic.

\section{P. baylei - R. cymodoce Chronozones $(109.25-91.87 \mathrm{~m})$}

The lower boundary of this combined chronozone interval is placed at the highest occurrence of $A$. cf. ernest $i$ at $109.25 \mathrm{~m}$. The ammonite fauna within the interval is non-diagnostic, being referred to Amoeboceras spp., and palynological samples yielded only rare algae. No diagnostic biostratigraphic events were recorded, and the in- terval is defined by the top of the $P$. baylei Chronozone beneath (last occurrence of $A$. cf. ernesti at $109.25 \mathrm{~m}$ ) and the base of the $R$. cymodoce Chronozone above (occurrence of Pachypictonia? at $91.87 \mathrm{~m}$ ).

\section{R. cymodoce Chronozone (91.87- $87.63 \mathrm{~m}$ )}

A relatively thin interval is referred to the $R$. cymodoce Chronozone based on the presence of the ammonite Pachypictonia? which defines the base of the chronozone at $91.87 \mathrm{~m}$.

\section{Ammonites}

Part of a large specimen was recorded at $91.87 \mathrm{~m}$ (Fig. $11 \mathrm{~F})$. It is evolute with strong, almost bullate primary ribs and weak secondaries. The level of furcation on the inner whorls is just hidden by the subsequent whorls, hence the strong primaries dominate the open, shallow umbilicus. The specimen is not sufficiently well preserved to identify it to species level, but its resemblance to ?Pachypictonia sp. C. Birkelund \& Callomon 1985 (plate 15, fig. 1) suggests it is assignable to Pachypictonia? It is considered to indicate faunal horizon M-16 within the $R$. cymodoce Chronozone.

\section{Dinoflagellates}

Assemblage. A poor assemblage of Glossodinium dimorphum, Gonyaulacysta jurassica and Sirmiodinium grossii was recorded in this chronozone.

Age

Early Kimmeridgian, Late Jurassic.

\section{A. mutabilis Chronozone (87.63-82.14 m)}

Ammonites are relatively common, occurring at four levels within this thin interval. The base of the $A$. mutabilis Chronozone is placed at the lowest occurrence of the ammonite $A$. cf. mutabilis at $87.63 \mathrm{~m}$.

\section{Ammonites}

Ammonites that occur at four levels between $87.63 \mathrm{~m}$ and $85.58 \mathrm{~m}$ (Figs 11G, H) include specimens of Aulacostephanus cf. mutabilis (Sowerby 1823). The specimens 
are parts of large, evolute forms. Inner whorls have strong and bullate primaries that curve on the lower flank and bifurcate just below the umbilical seam of the subsequent whorl. Later ribbing becomes less strong to weak, and primaries divide into three to four secondaries. In view of the fragmentary preservation, the material is referred to as $A$. cf. mutabilis. A. mutabilis represents faunal horizon M-19 and the $A$. mutabilis Chronozone.

\section{Dinoflagellates}

Assemblage. A poor assemblage of Gonyaulacysta jurassica, Sirmiodinium grossii, Endoscrinium galeritum and Systematophora spp. was recorded in this chronozone.

\section{Age}

Middle Kimmeridgian, Late Jurassic

\section{A. eudoxus Chronozone (82.14-59.39 m)}

Ammonites were recorded at only one level in the $A$. eudoxus Chronozone and the chronozone definition and age assignment rest primarily on the dinoflagellate cyst assemblages. The base of the chronozone is placed at the lowest occurrence of the dinoflagellate $P$. pannosum at $82.14 \mathrm{~m}$.

\section{Ammonites}

The uppermost ammonite-bearing level in the Blokelv-1 core is at $81.93 \mathrm{~m}$, just $21 \mathrm{~cm}$ above the base of the $A$. eudoxus Chronozone. The ammonite is crushed and fragmented (Fig. 11I). Ribs are dense and regularly spaced. The degree of involution, ribbing density and ribs that are curved on the umbilical shoulder and then straight and almost rectiradiate on the flanks suggest identification of Amoeboceras (Euprionodoceras) cf. kochi Spath 1935. A. kochi is the index of the lowermost horizon (M20) of the A. eudoxus Chronozone.

\section{Dinoflagellates}

Assemblage. Dominated by Perisseiasphaeridium pannosum in association with Circulodinium distinctum and Cribroperidinium spp.

Stratigraphy. In Milne Land, the first occurrence of abundant Perisseiasphaeridium pannosum is recorded in the lowermost $A$. eudoxus Chronozone, in ammonite faunal horizon M-20 (Piasecki 1996) and this event is used in the Blokelv-1 section to define the base of the chronozone. The last occurrence of abundant $P$. pannosum in Milne Land was recorded near the top of the $A$. eudoxus Chronozone, above ammonite faunal horizon M-22 (Piasecki 1996); this event occurs at $68.97 \mathrm{~m}$ in the Blokelv-1 section.

Age

Middle Kimmeridgian, Late Jurassic.

\section{A. autissiodorensis Chronozone (59.39-10.00)}

Recognition of the chronozone is based on its dinoflagellate cyst assemblages since ammonites were not recorded. The base of the chronozone is placed at the lowest occurrence of the dinoflagellate cyst $O$. patulum at $59.39 \mathrm{~m}$.

\section{Dinoflagellates}

Assemblage. Dominated by Oligosphaeridium patulum and Cribroperidinium spp. in association with Circulodinium distinctum, Perisseiasphaeridium pannosum, Rhynchodiniopsis spp. and Senoniasphaera clavellii.

Stratigraphy. In Milne Land, the first occurrence of abundant Oligosphaeridium patulum is recorded at the base of the $A$. autissiodorensi Chronozone between ammonite faunal horizons M-22 and M-23 (Piasecki 1996); this event is thus used to place the base of the chronozone at $59.39 \mathrm{~m}$ in the Blokelv-1 section.

Age

Latest Kimmeridgian, Late Jurassic.

\section{P. elegans Chronozone (10.00-0.00 m)}

The chronozone boundaries and age of this interval are based on its dinoflagellate cyst assemblages; no ammonites were recorded in this interval. The first (lowest) indication of the chronozone is the appearance of the dinoflagellate cyst $R$. martonense at $2.96 \mathrm{~m}$, the first occurrence of which is known to be somewhat above the base of the P. elegans Chronozone (Piasecki 1996). The lower 
boundary is arbitrarily placed at $10.00 \mathrm{~m}$, at the base of the Sjællandselv Member.

\section{Dinoflagellates}

Assemblage. Dominated by Oligosphaeridium patulum and Cribroperidinium spp. in association with Circulodinium distinctum, Rhynchodiniopsis spp. and Senoniasphaera spp.

Stratigraphy. Abundant Oligosphaeridium patulum occurs to the top of the Blokelv- 1 borehole (sample at 0.00 $\mathrm{m}$ ); note that the top of the recovered cored section is at $1.72 \mathrm{~m}$ and the uppermost palynological sample was taken from surface exposure at the drill site. In Milne Land, the highest occurrence of abundant Oligosphaeridium patulum was recorded below the $P$. wheatleyensis Chronozone, below the ammonite faunal horizon M-25 (Piasecki 1996). The presence of Rhychodiniopsis martonense in the interval is indicative of the P. elegans Chronozone as this species was not recorded above the $P$. elegans Chronozone and ammonite faunal horizon M-24 in Milne Land (Piasecki 1996).

Age

Earliest Volgian, Late Jurassic.

\section{Discussion}

The combined ammonite and dinoflagellate stratigraphy in Blokelv-1 provides a detailed subdivision and dating of the drilled succession. Separately, ammonite and dinoflagellate stratigraphies would have provided data for only parts of the core. Published biostratigraphic studies of the Jurassic of Jameson Land mostly concern macrofossils, especially ammonites. The few published palynological studies have focused particularly on the Lower to Middle Jurassic (e.g. Koppelhus \& Dam 2003; Koppelhus \& Hansen 2003). Upper Jurassic palynological studies have been presented as survey and consultancy reports and remain unpublished.

Kelly et al. (2015) recently published a review of the Jurassic biostratigraphy of East Greenland in which they applied Upper Jurassic dinoflagellate stratigraphic schemes from two studies related to the North Sea/ North Atlantic by Partington et al. (1993) and Poulsen \& Riding (2003). It is notable, however, that neither of these schemes contain data from the Upper Jurassic of East Greenland. There are undoubtedly many similarities between the dinoflagellate stratigraphies in the North Sea/North Atlantic and in East Greenland, but it is considered somewhat premature to apply distant datasets to another region without the support of local data.

\section{Stratigraphic conclusions}

Lithostratigraphically, the Blokelv-1 borehole encountered two members of the Hareelv Formation, the Katedralen Member (233.80 (TD) - $10.00 \mathrm{~m}$ ) and the Sjællandselv Member (10.00-0.00 m). The base of the Katedralen Member was not reached and the unit thus has a thickness in excess of $225 \mathrm{~m}$ in this area. This exceeds that predicted for this area based on the first mapping campaign (an estimate of $c .200 \mathrm{~m}$ was made by Surlyk et al. (1973), but is within the thickness range estimated for the Hurry Inlet region (200-400 m in Surlyk \& NoeNygaard 2001).

The cored succession is dated as Middle Oxfordian to earliest Volgian using ammonites and dinoflagellates, and the succession is subdivided into ammonite chronozones. All middle Oxfordian - lower Volgian chronozones have been identified in the core. The stratigraphic resolution is variable, however, and combined, undifferentiated chronozones were recognised in the upper Oxfordian $(A$. serratum - A. glosense and $A$. regulare - $A$. rosenkrantzi) and the lower Kimmeridgian (P. baylei - R. cymodoce). Given the present stratigraphic resolution, the succession appears to represent continuous deposition from the middle Oxfordian to the earliest Volgian, as no hiatus was recognised.

The zonation allows a detailed correlation of the Blokelv- 1 core to, and a framework for, other shallow cores and outcrops in the Jameson Land Basin (Fig. 12), and it contributes to an understanding of the depositional history of the basin (Bjerager et al. 2018, this volume). In addition, it supports correlation of the Katedralen Member source rock in the Blokelv-1 core with 'Kimmeridge Clay' equivalents in the North Atlantic region (BojesenKoefoed et al. 2018, this volume) and the Barents Shelf (Leith et al. 1993).

The nature of the palynological record supports the interpretation that the sediments of the Katedralen Member in the Blokelv-1 core were deposited in dominantly anoxic bottom conditions that resulted in the preservation of abundant organic material. The Oxfordian mudstones contain abundant terrestrial matter compared to the marine-dominated organic matter of the 


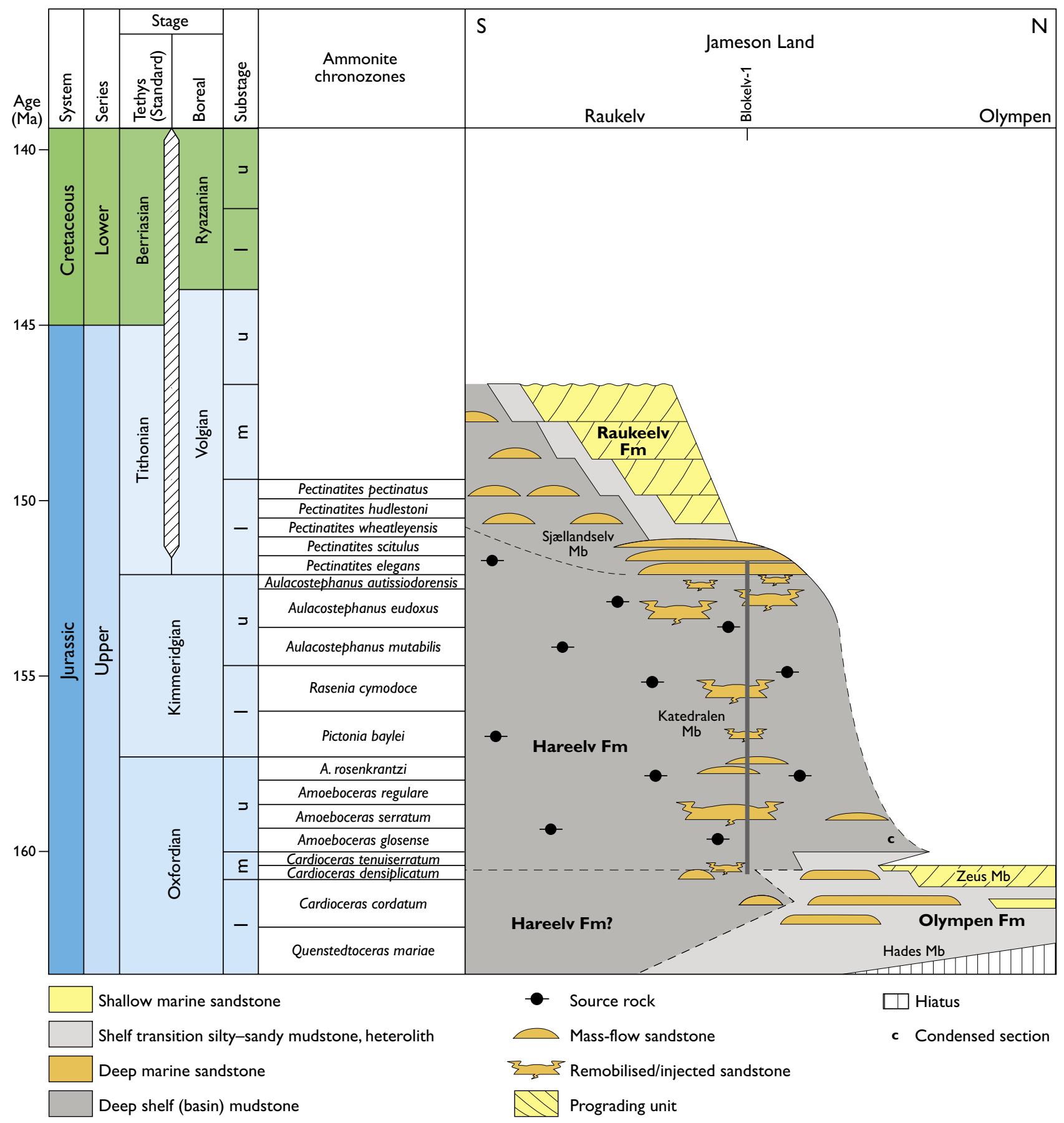

Fig. 12. Scheme of the Upper Jurassic in the Jameson Land Basin showing the stratigraphic position and extent of the Blokelv-1 core.

Kimmeridgian mudstones, as confirmed by geochemical analysis (Bojesen-Koefoed et al. 2018, this volume). Nevertheless, the entire mudstone section represents a goodexcellent source rock and the difference in source-rock quality between the Oxfordian and Kimmeridgian mud- stones is surprisingly small (Bojesen-Koefoed et al. 2018, this volume). The Sjællandselv Member, in contrast, has no potential for hydrocarbons with a low organic content of black woody material. 


\section{Acknowledgements}

Jette Halskov and Stefan Sølberg prepared the figures, and Annette Ryge and Dorthe Samuelsen prepared the palynological samples. We appreciate the useful comments and suggestions from the two referees W.A.P. Wimbledon and M. Smelror.

\section{References}

Århus, N. 1988. Palynostratigraphy of some Bathonian-Hauterivian sections in the Arctic, with emphasis on the Janusfjellet Formation type section, Spitsbergen. IKU-Report 23.1252.11/01/88, 139 pp.

Birkelund, T. \& Callomon, J.H. 1985: The Kimmeridgian ammonite faunas of Milne Land, central East Greenland. Bulletin Grønlands Geologiske Undersøgelse 153, 56 pp.

Birkelund, T., Callomon, J.H. \& Fürsich, F.T. 1984: The stratigraphy of the Upper Jurassic and Lower Cretaceous sediments of Milne Land, central East Greenland. Bulletin Grønlands Geologiske Undersøgelse 147, $56 \mathrm{pp}$.

Bjerager, M., Alsen, P. Bojesen-Koefoed, J.A., Piasecki, S. \& Pilgaard, A. 2018: Late Jurassic evolution of the Jameson Land Basin, East Greenland - implications of the Blokelv-1 borehole. In: Ineson, J. \& Bojesen-Koefoed, J.A. (eds): Petroleum geology of the Upper Jurassic - Lower Cretaceous of East and North-East Greenland: Blokelv-1 borehole, Jameson Land Basin. Geological Survey of Denmark and Greenland Bulletin 42, 149-168 (this volume).

Bojesen-Koefoed, J.A., Bjerager, M. \& Piasecki, S. 2009: Shallow core drilling and petroleum geology related fieldwork in East and North-East Greenland 2008. Geological Survey of Denmark and Greenland Bulletin 17, 53-56.

Bojesen-Koefoed, J.A., Alsen, P. \& Christiansen, F.G. 2014: Six years of petroleum geological activities in North-East Greenland (2008-2013): highlights and a view of the future. In: Bennike, O., Garde, A.A. \& Watt, W.S. (eds): Review of Survey activities 2013. Geological Survey of Denmark and Greenland Bulletin 31, 59-62.

Bojesen-Koefoed, J.A., Bjerager, M., Nytoft, H.P., Petersen, H.I., Piasecki, S. \& Pilgaard, A. 2018: Petroleum potential of the Upper Jurassic Hareelv Formation, Jameson Land, East Greenland. In: Ineson, J. \& Bojesen-Koefoed, J.A. (eds): Petroleum geology of the Upper Jurassic - Lower Cretaceous of East and North-East Greenland: Blokelv-1 borehole, Jameson Land Basin. Geological Survey of Denmark and Greenland Bulletin 42, 85-113 (this volume).

Brekke, H., Dahlgren, S., Nyland, B. \& Magnus, C. 1999: The prospectivity of the Vøring and Møre basins on the Norwegian Sea continental margin. In: Fleet, A.J. \& Boldy, S.A.R. (eds): Petroleum geology of Northwest Europe: proceedings of the 5th conference, 261-274. London: Geological Society.

Brekke, H., Sjulstad, H.I., Magnus, C. \& Williams, R, 2001: Sedimentary environments offshore Norway - an overview. In: Martinsen, O.J. \& Dreyer, T. (eds): Sedimentary Environments Offshore Norway - Palaeozoic to Recent. Norwegian Petroleum Society (NPF) Special Publications 10,7-37.

Callomon, J.H. 1985: The evolution of the Jurassic ammonite fam- ily Cardioceratidae. In: Cope, J.C.W. \& Skelton, P.R. (eds): Special Papers in Palaeontology 33, 49-90. London: Palaeontological Association.

Callomon, J.H. 1993: The ammonite succession in the Middle Jurassic of East Greenland. Bulletin of the Geological Society of Denmark 40, 83-113.

Callomon, J.H. 2003: The Middle Jurassic of western and northern Europe: its subdivisions, geochronology and correlations. In: Ineson, J.R. \& Surlyk, F. (eds): The Jurassic of Denmark and Greenland. Geology of Denmark and Greenland Bulletin 1, 61-73.

Callomon, J.H. \& Birkelund, T. 1980: The Jurassic transgression and the mid-Late Jurassic succession in Milne Land, central East Greenland. Geological Magazine 117, 211-226.

Callomon, J.H. \& Birkelund, T. 1982: The ammonite zones of the Boreal Volgian (Upper Jurassic) in East Greenland. In: Embry, A.F.B. \& Balkwill, H.R. (eds): Arctic geology and geophysics, Canadian Society of Petroleum Geologists Memoir 8, 349-369.

Callomon, J.H., Alsen, P. \& Surlyk, F. 2015: The ammonites of the Middle Jurassic Cranocephalites beds of East Greenland. Geological Survey of Denmark and Greenland Bulletin 34, 145 pp.

Dam, G., Surlyk, F., Mathiesen, A. \& Christiansen, F.G. 1995: Exploration significance of lacustrine forced regressions of the Rhaetian-Sinemurian Kap Stewart Formation, Jameson Land, East Greenland. In: Steel, R.J. et al. (eds): Sequence stratigraphy on the Northwest European margin. Norwegian Petroleum Society (NPF) Special Publications 5, 511-527.

Gautier, D.L. 2007: Assessment of undiscovered oil and gas resources of the East Greenland Rift Basins Province. U.S. Geological Survey Fact Sheet 2007-3077, 4 pp.

Gautier, D.L. et al. 2011: Assessment of NE Greenland: prototype for development of Circum-Arctic resource appraisal methodology. Memoir of the Geological Society (London) 35, 663-672.

Gradstein, F.M., Ogg, J., Schmitz, M. \& Ogg, G. 2012 (eds): The Geologic Time Scale 2012, 1176 pp. Elsevier.

Hamann, N.E., Whittaker, R.C. \& Stemmerik, L. 2005: Geological development of the Northeast Greenland Shelf. In: Doré, A.G. \& Vining, A.A. (eds): Petroleum geology: North-West Europe and global perspectives - proceedings of the 6th Petroleum Geology Conference, 887-902. London: Geological Society.

Håkansson, E., Birkelund, T., Piasecki, S. \& Zakharov, V. 1981: Jurassic-Cretaceous boundary strata of the extreme arctic (Peary Land, North Greenland). Bulletin of the Geological Society of Denmark 30, 11-42.

Kelly, S.R.A., Gregory, J., Braham, W., Strogen, D.P. \& Whitham, A.G. 2015: Towards an integrated Jurassic biostratigraphy for eastern Greenland. Volumina Jurassica XIII (1), 43-64.

Koppelhus, E.B. \& Dam, G. 2003: Palynostratigraphy and palaeoenvironments of the Rævekløft, Gule Horn and Ostreaelv Formations (Lower-Middle Jurassic), Neill Klinter Group, Jameson Land, East Greenland. In: Ineson, J.R. \& Surlyk, F. (eds): The Jurassic of Denmark and Greenland. Geological Survey of Denmark and Greenland Bulletin 1, 723-775.

Koppelhus, E.B. \& Hansen, C.F. 2003: Palynostratigraphy and palaeoenvironment of the Middle Jurassic Sortehat Formation (Neill Klinter Group), Jameson Land, East Greenland. In: Ineson, J.R. \& 
Surlyk, F. (eds): The Jurassic of Denmark and Greenland. Geological Survey of Denmark and Greenland Bulletin 1, 777-811.

Larsen, H.C. \& Marcussen, C. 1992: Sill intrusion, flood basalt emplacement and deep crustal structure of the Scoresby Sund region. In: Storey, B.C., Alabaster, T. \& Pankhurst, R.J. (eds): Magmatism and the causes of continental break-up. Geological Society Special Publication (London) 68, 365-386.

Larsen, M., Piasecki, S. \& Surlyk, F. 2003: Stratigraphy and sedimentology of a basement-onlapping shallow marine sandstone succession, the Charcot Bugt Formation, Middle-Upper Jurassic, East Greenland. In: Ineson, J.R. \& Surlyk, F. (eds): The Jurassic of Denmark and Greenland. Geological Survey of Denmark and Greenland Bulletin 1, 893-930.

Leith, T.L. et al. 1993: Mesozoic hydrocarbon source-rocks of the Arctic region. Norwegian Petroleum Society Special Publications 2, 1-25.

Milner, P.S. \& Piasecki, S. 1996: Boreal Middle Jurassic dinoflagellate cyst stratigraphy of Jameson Land, East Greenland. In: Piasecki, S. et al. (eds): Formation of source and reservoir rocks in a sequence stratigraphic framework, Jameson Land, East Greenland. Energy Research Programme EFP-93, Projects 1313/93-0010 \& 0017. Danmarks og Grønlands Geologiske Undersøgelse Rapport 1996/30, Volume II, Appendix 12, 46 pp.

Nøhr-Hansen, H. \& Piasecki, S. 2002: Paleocene sub-basaltic sediments on Savoia Halvø, East Greenland. Geology of Greenland Survey Bulletin 191, 111-116.

Page, K.N. 2003: The Lower Jurassic of Europe: its subdivision and correlation. In: Ineson, J.R. \& Surlyk, F. (eds): The Jurassic of Denmark and Greenland. Geology of Denmark and Greenland Bulletin 1, 23-59.

Partington, M.A., Copestake, P., Mitchener, B.C., Underhill, J.R. 1993: Biostratigraphic calibration of genetic stratigraphic sequences in the Jurassic - lowermost Cretaceous (Hettangian to Ryazanian) of the North Sea and adjacent areas. In: Parker, J.R. (ed.): Petroleum geology of Northwest Europe: proceedings of the 4th Conference, 371-386. London: Geological Society.

Piasecki, S. 1979: Hauterivian dinoflagellate cysts from Milne Land, East Greenland. Bulletin of the Geological Society of Denmark 28, 31-37.

Piasecki, S. 1981: Middle to Late Jurassic dinoflagellate cyst stratigraphy from Milne Land and Jameson Land (East Greenland) correlated with ammonite stratigraphy, $167 \mathrm{pp}$. Unpublished Licentiat thesis (PhD), University of Copenhagen, Denmark.

Piasecki, S. 1996: Boreal dinoflagellate cyst stratigraphy of Middle to Upper Jurassic sediments of Milne Land, East Greenland. In: Piasecki, S. et al. (eds): Formation of source and reservoir rocks in a sequence stratigraphic framework, Jameson Land, East Greenland. Energy Research Programme EFP-93, Projects 1313/93-0010 \& 0017. Danmark og Grønlands Geologiske Undersøgelse Rapport 1966/30, Volume II, Appendix 13, 100 pp.

Piasecki. S. \& Stemmerik, L. 2004: Jurassic dinoflagellate cysts from Hochstetter Forland, North-East Greenland. In: Stemmerik, L. \& Stouge, S. (eds): The Jurassic of North-East Greenland. Geological Survey of Denmark and Greenland Bulletin 5, 87-97.

Piasecki, S., Callomon, J.H., Stemmerik, L. 2004b: Jurassic dinoflag- ellate cyst stratigraphy of Store Koldewey, North-East Greenland. Geological Survey of Denmark and Greenland Bulletin 5, 99-112.

Piasecki, S., Larsen, M., Therkelsen, J., Vosgerau, H. 2004a: Jurassic dinoflagellate cyst stratigraphy of Hold with Hope, North-East Greenland. Geological Survey of Denmark and Greenland Bulletin 5, 73-88.

Poulsen, N.E. 1985: Dinocystestratigrafien i den nedre del av Hareelv Formation (øvre jura), Jameson Land, Østgrønland. Dansk Geologiske Forening Årsskrift 1984, 133-137.

Poulsen, N.E. \& Riding, J.B. 2003: The Jurassic dinoflagellate cyst zonation of Subboreal Northwest Europe. In: Ineson, J.R. \& Surlyk, F. (eds): The Jurassic of Denmark and Greenland. Geological Survey of Denmark and Greenland Bulletin 1, 115-144.

Riding, J.B. \& Thomas, J.E. 1992: Dinoflagellate cysts of the Jurassic System. In: Powell, A.J. (ed.): A stratigraphic index of dinoflagellate cysts. British Micropalaeontological Society Publication Series, 7-97. London: Chapman and Hall.

Rosenkrantz, A. 1929: Preliminary account of the geology of the Scoresby Sound district. In: Koch, L. (ed.): The geology of East Greenland. Meddelelser om Grønland 73(2), 135-154.

Smelror, M. 1988: Late Bathonian to Early Oxfordian dinoflagellate cyst stratigraphy of Jameson Land and Milne Land, East Greenland. Rapport Grønlands Geologiske Undersøgelse 137, 135-159.

Spath, L.F. 1935: The Upper Jurassic invertebrate faunas of Cape Leslie, Milne Land. I. Oxfordian and Lower Kimmeridgian. Meddelelser om Grønland 99(2), 82 pp.

Spath, L.F. 1936: The Upper Jurassic invertebrate faunas of Cape Leslie, Milne Land. II. Upper Kimmeridgian and Portlandian. Meddelelser om Grønland 99(3), 180 pp.

Surlyk, F. 1978: Submarine fan sedimentation along fault scarps on tilted fault blocks (Jurassic-Cretaceous boundary, East Greenland). Bulletin Grønlands Geologiske Undersøgelse 128, 108 pp.

Surlyk, F. 1991: Sequence stratigraphy of the Jurassic - lowermost Cretaceous of East Greenland. AAPG Bulletin 75, 1468-1488.

Surlyk, F. 2003: The Jurassic of East Greenland: a sedimentary record of thermal subsidence, onset and culmination of rifting. In: Ineson, J.R. \& Surlyk, F. (eds): The Jurassic of Denmark and Greenland. Geological Survey of Denmark and Greenland Bulletin 1, 659-722.

Surlyk, F. \& Noe-Nygaard, N. 2001: Sand mobilisation and intrusion in the Upper Jurassic Hareelv Formation of East Greenland. In: Surlyk, F. \& Håkansson, (eds): Oscar volume. Bulletin of the Geological Society of Denmark 48, 169-188.

Surlyk, F., Callomon, J.H., Bromley, R.G. \& Birkelund, T. 1973: Stratigraphy of the Jurassic - Lower Cretaceous sediments of Jameson Land and Scoresby Land, East Greenland. Bulletin Grønlands Geologiske Undersøgelse 105, 76 pp.

Sykes, R.M. \& Callomon, J.H. 1979: The Amoeboceras zonation of the Boreal Upper Oxfordian. Palaeontology 22, 839-903.

Sykes, R.M. \& Surlyk, F. 1976: A revised ammonite zonation of the Boreal Oxfordian and its application in northeast Greenland. Lethaia 9, 421-436.

Vosgerau, H., Larsen, M., Piasecki, S. \& Therkelsen, J. 2004: A new Middle-Upper Jurassic succession on Hold with Hope, North-East Greenland. Geological Survey of Denmark and Greenland Bulletin 5, 51-71. 
Wierzbowski, A., Smelror, M. \& Mørk, A., 2002: Ammonites and dinoflagellates in the Upper Oxfordian and Kimmeridgian of the northeastern Norwegian Sea (Nordland VII offshore area): biostratigraphical and biogeographical significance. Neues Jahrbuch für Geologie und Paläontologie, Abhandlungen 226, 145-164.

Woollam, R. \& Riding, J.B. 1983: Dinoflagellate cyst stratigraphy of the English Jurassic. Institute of Geological Sciences Report 83/2, 44 pp.
Zeiss, A. 2003: The Upper Jurassic of Europe: its subdivision and correlation. In: Ineson, J.R. \& Surlyk, F. (eds): The Jurassic of Denmark and Greenland. Geological Survey of Denmark and Greenland Bulletin 1,75-114.

Ziegler, P.A. 1982: Geological Atlas Western and Central Europe, 130 pp. Amsterdam: Elsevier.

Manuscript received 4 December 2015; revision accepted 1 May 2018 